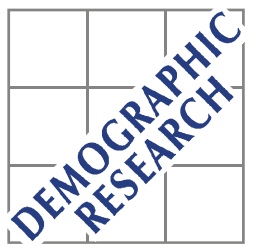

Demographic Research a free, expedited, online journal of peer-reviewed research and commentary in the population sciences published by the Max Planck Institute for Demographic Research Konrad-Zuse Str. 1, D-18057 Rostock · GERMANY www.demographic-research.org

DEMOGRAPHIC RESEARCH

VOLUME 22, ARTICLE 26, PAGES 813-862

PUBLISHED 04 MAY 2010

http://www.demographic-research.org/Volumes/Vol22/26/

DOI: $10.4054 /$ DemRes.2010.22.26

Research Article

\title{
Comparisons of infant mortality in the Austrian Empire Länder using the Tafeln (1851-54)
}

\section{Gianpiero Dalla-Zuanna}

\section{Fiorenzo Rossi}

(C) 2010 Gianpiero Dalla-Zuanna \& Fiorenzo Rossi.

This open-access work is published under the terms of the Creative Commons Attribution NonCommercial License 2.0 Germany, which permits use, reproduction \& distribution in any medium for non-commercial purposes, provided the original author(s) and source are given credit.

See http:// creativecommons.org/licenses/by-nc/2.0/de/ 


\section{Table of Contents}

$\begin{array}{lll}1 & \text { Introduction } & 814\end{array}$

$2 \quad$ Typology and quality of data $\quad 817$

3 Life tables for ages $0-3$ for the cohort born in 1851

4 A brief discussion of territorial differences $\quad 846$

$5 \quad$ Was there discrimination against female children? 847

$\begin{array}{lll}6 & \text { Conclusions } & 857\end{array}$

$\begin{array}{ll}\text { References } & 860\end{array}$ 


\title{
Comparisons of infant mortality in the Austrian Empire Länder using the Tafeln (1851-54)
}

\author{
Gianpiero Dalla-Zuanna ${ }^{1}$
}

Fiorenzo Rossi ${ }^{2}$

\begin{abstract}
In this paper we measure differences in infant mortality among the central European populations of the Austrian Empire during the mid-19th century using data published in the Tafeln zur Statistik der Österreichischen Monarchie (Statistical Tables of the Austrian Monarchy). Our aim is mainly methodological, i.e., to illustrate the extraordinary richness of this data, and to discuss whether the quality of the material on infant mortality published around 1850 in the Tafeln guarantees comparability between regions. This article demonstrates that - with several exceptions - the quality of the material on infant mortality published in the Tafeln around 1850 guarantees reliable comparability between the Empire's Länder. Data on sex, age at death, and legitimacy were all recorded with great accuracy. This article - of a methodological nature provides only a few examples of potential analyses which might be carried out using such rich and detailed territorial data. The geography of mortality in the first three years of life varied by age, but according to intervals different than those usually employed when studying early mortality. Four ages can be identified (first month, months 1-5, months 6-17, and months 18-35) with a geography of differing mortality. In all likelihood, in these four age groups, mortality differences between Länder were motivated by diverse reasons.
\end{abstract}

\footnotetext{
${ }^{1}$ University of Padua, Department of Statistical Sciences.

${ }^{2}$ University of Padua, Department of Statistical Sciences.
} 


\section{Introduction}

In this paper we measure differences in infant mortality among the central European populations of the Austrian Empire during the mid- $19^{\text {th }}$ century using data published in the Tafeln zur Statistik der Österreichischen Monarchie (Statistical Tables of the Austrian Monarchy). Our aim is mainly methodological, i.e., to illustrate the extraordinary richness of this data, and to discuss whether the quality of the material on infant mortality published around 1850 in the Tafeln guarantees comparability between regions. A brief premise concerning the meaning of such an analysis provides additional support for this important methodological investigation.

Over the last few decades, numerous studies have sought to explain historical differences in the risk of dying during the earliest stages of life (see, e.g., Vallin 1991; Lee 1991; Preston and Haines 1991; Bideau, Desjardins, and Pérez Brignoli 1997; Corsini and Viazzo 1997; Bengtsson, Campbell, and Lee 2004; Breschi and Pozzi 2004). Thus far, however, a complete comparative map of infant mortality for the regions of Europe from 1650-1900 is not available. Two important patterns remain less than fully explained. First, although the risk of dying during the first year of life during the ancien régime was everywhere higher than $100 \%$, considerable differences existed between populations living in adjacent regions and countries (Livi Bacci 1997: point 2). Second, secular trends may have significantly varied between neighbouring populations (Livi Bacci 1997: point 6). Although these issues are not easily disentangled, they are crucial to understanding the historical determinants of infant mortality. The Tafeln are potentially an important source for examining infant mortality in the Austrian Empire during the first half of the $19^{\text {th }}$ century, and for exploring the patterns mentioned above. In this paper, we focus on the first pattern, measuring differences in infant mortality among mid- $19^{\text {th }}$-century Länder through use of published data in the Tafeln. The second issue will be analysed in the near future. ${ }^{3}$

The Tafeln include about 20 of the large Empire's Länder (regions), which during 1815-1861 were home to about 35 million people, and extended from Milan, now in Italy, to Ternopil, now in Ukraine (about 1,200 km West-East); and from Krakow, now in Poland, to Kotor, now in Montenegro (about 1,000 km North-South). This area was characterised by much orographic, climatic, cultural, religious, linguistic and economic

\footnotetext{
${ }^{3}$ This article represents the first product of a larger research project on the demographic exploitation of the Tafeln zur Statistik der Österreichischen Monarchie, funded by the Max Planck Institute for Demographic Research of Rostock (Germany). We thank all participants in the seminar held at the Max Plank Institute of Rostock in January 2009 - especially Joshua Goldstein and Chris Wilson - for their comments and suggestions. We also express our gratitude to the anonymous referees for their reactions and comments to the first draft of this paper.
} 
diversity (Table 1 and Figure 1). On the other hand, given the common political (and centralistic) administration across the Länder, it is possible that data was collected following similar norms and procedures. With regard to several aspects concerning infant mortality this is only partially true, although territorial comparability indubitably remains better than in other ancien régime contexts. Moreover, the Tafeln are now available for the period of 1829-65, albeit with different details and territorial coverage. The latter include not only a plethora of demographic information, but also data on the economy and social life. Finally, several time series are long enough to allow for a comparison of temporal trends.

In the following section, we discuss the typology of the data and their quality (completeness, age-heaping, etc.). In the third section, we illustrate the methodology employed to build a life table for the first three years of age for the cohort born in 1851 . Age at death is classified in months for the first three months of life, quarterly until the first birthday, bi-yearly until the second birthday, and then annually for the third year of life. For each region, it is possible to calculate life tables for these ages by sex and legitimacy. Data on stillbirths were also collected, although their quality seems relatively poor. The last sections are dedicated to a preliminary discussion of the differences in infant mortality among the Austrian Empire Länder during the mid-19 ${ }^{\text {th }}$ century.

\section{Figure 1: $\quad$ The Austrian Empire and its Länder}

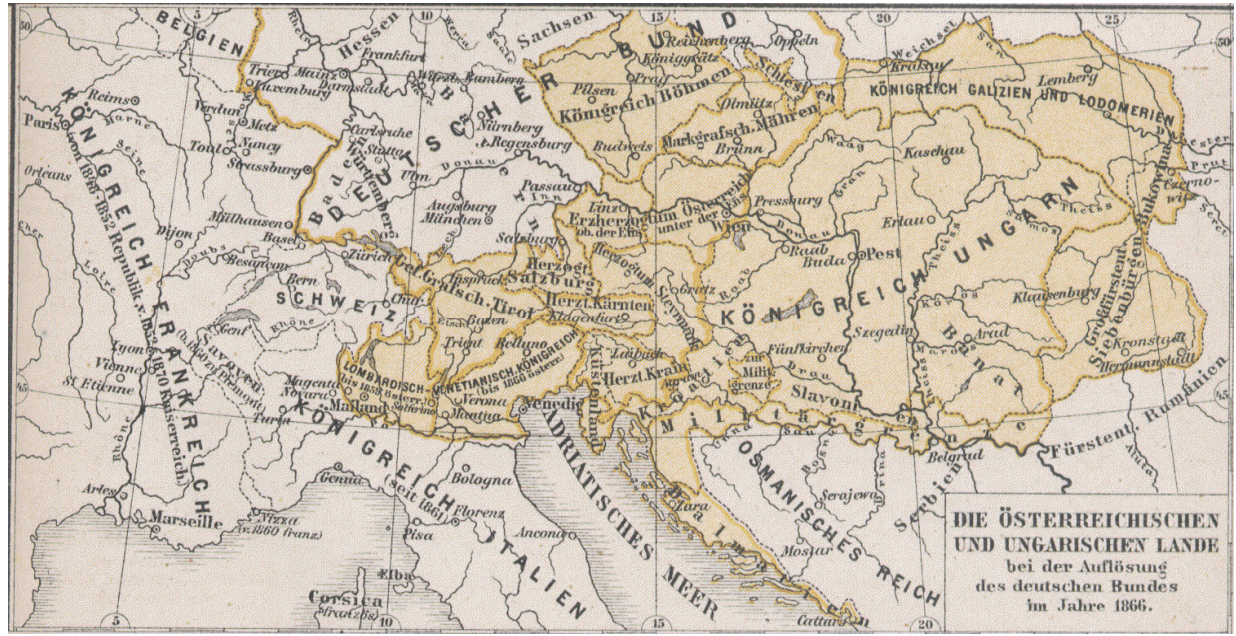

Source: Meners Konversation-Lexicon, Vol. 15, Leipzig und Wien, Bibliographisches Institut, 1896. 
Table 1: $\quad$ Population of the Länder of the Austrian Empire, 1.1.1851

\begin{tabular}{|c|c|c|c|c|c|}
\hline $\mathbf{n}$ & Länder & Males & Females & Total & $\begin{array}{c}\% \text { of total } \\
\text { Empire }\end{array}$ \\
\hline 1 & Oesterreich unter der Enns & 750,092 & 787,955 & $1,538,047$ & 4.23 \\
\hline 2 & Oesterreich ob der Enns & 338,041 & 368,275 & 706,316 & 1.94 \\
\hline 3 & Salzburg & 70,032 & 75,975 & 146,007 & 0.40 \\
\hline 4 & Steiermark & 487,124 & 518,820 & $1,005,944$ & 2.76 \\
\hline 5 & Kärnthen & 150,579 & 168,645 & 319,224 & 0.88 \\
\hline 6 & Krain & 219,756 & 244,200 & 463,956 & 1.27 \\
\hline 7 & $\begin{array}{l}\text { Görz, Gradisca, Istrien, Triest } \\
\text { sammt Gebiet }\end{array}$ & 270,548 & 272,369 & 542,917 & 1.49 \\
\hline 8 & Tirol und Vorarlberg & 422,439 & 435,764 & 858,203 & 2.36 \\
\hline 9 & Böhmen & $2,058,645$ & $2,327,249$ & $4,385,894$ & 12.05 \\
\hline 10 & Mähren & 845,734 & 954,104 & $1,799,838$ & 4.94 \\
\hline 11 & Schlesien & 202,991 & 235,595 & 438,586 & 1.20 \\
\hline $12-13$ & Krakau und Galizien & $2,198,477$ & $2,357,000$ & $4,555,477$ & 12.52 \\
\hline 14 & Bukowina & 188,873 & 191,953 & 380,826 & 1.05 \\
\hline 15 & Dalmatien & 195,871 & 197,844 & 393,715 & 1.08 \\
\hline 16 & Lombardie & $1,383,874$ & $1,360,244$ & $2,744,118$ & 7.54 \\
\hline 17 & Venedig & $1,134,377$ & $1,145,622$ & $2,279,999$ & 6.26 \\
\hline 18 & Ungern & $3,889,269$ & $3,974,993$ & $7,864,262$ & 21.61 \\
\hline 19 & $\begin{array}{l}\text { Serbische Wojwodschaft und } \\
\text { Temeser Banat }\end{array}$ & 716,580 & 709,641 & $1,426,221$ & 3.92 \\
\hline 20 & Kroatien und Slavonien & 434,449 & 434,007 & 868,456 & 2.39 \\
\hline 21 & Siebenbürgen & $1,028,577$ & $1,045,160$ & $2,073,737$ & 5.70 \\
\hline \multirow[t]{3}{*}{22} & Militärgränze & 450,739 & 508,138 & 958,877 & 2.63 \\
\hline & Hierzu das k. K. Militar & 648,000 & - & 648,000 & 1.78 \\
\hline & Total Empire & $18,085,067$ & $18,313,553$ & $36,398,620$ & 100.00 \\
\hline
\end{tabular}




\section{Typology and quality of data}

As mentioned above, the data come from a large collection of information known as the Tafeln. Published between 1829 and 1871 (referencing the period of 1828-65), the Tafeln zur Statistik der Österreichischen Monarchie represent an important stage in the history of public statistics. The evolution of the quantity and quality of the statistics is quite evident. Beginning with only a small office within the Accounting Governance Checks, the management of statistics later passed, in 1840, to the Statistical Administrative Directorate under the Presidium of the Accounting General Directorate; in 1848, it was moved again, this time directly under the Ministry of Commerce, Industry, and Public Works. The first edition contained 104 statistical tables addressing a variety of topics: territory and population, the economy, justice, schools, administration, etc. The 1846 edition (containing data collected in 1841) was renovated in part through the use of printed lead characters, which replaced the manual lithographic edition which preceded it. In addition, the data (with the exception of military and financial information) were made public; beginning in 1846, the Tafeln became available in many public libraries. In 1856, a new series was published, containing data from the period 1849-1856. Starting in 1860, the Tafeln came out every five years. The last edition was published in 1871, using data from 1860-1865. In the years that followed, the Tafeln were substituted by statistical yearbooks and periodical publications focusing on specific issues.

Data relative to the period of 1851-1854 are particularly rich and detailed. Of interest to this paper, births and deaths were recorded in terms of vitality, legitimacy, and sex (eight modalities in total). Death during the first three years of life was differentiated according to nine separate age classifications, as indicated above. Data are available for all of the Länder, with only a few exceptions (see Table 2).

Religious authorities (priests in the Catholic parishes, pastors in the Protestant parishes, rabbis in the Jewish communities, etc.) also served as civil status officials. In this capacity they were responsible, on behalf of the State, for updating the standardised and pre-printed registers of weddings, births, and deaths (which often mirrored those of religious nature). The Tafeln calculations are based upon the data contained in these civil registers.

Serious setbacks impeding access to reliable information arise for only three Länder. For Oesterreich unter der Enns, there are no data on deaths in Vienna for the years 1851 and 1852; births were reported separately for these years. We attempted to build mortality measures for this Land, with the exclusion of Vienna, for the years 1851 and 1852, but the results are somewhat suspect. Consequently, they are not considered in this paper. For Dalmatien, there are no data on deaths for any of the four years under consideration. For Kroatien und Slavonien, data on deaths are similarly lacking for the 
first three years, while data on births are missing for 1851. Other shortages of data or discrepancies can be overcome. For example, data on both births and deaths for Görz, Gradisca und Istrien were published separately from Triest sammt Gebiet only in the year 1851; in this paper, we always combine them. For the following three Länder, Lombardie, Venedig, and Serbische Wojwodschaft und Temeser Banat, the number of births $\left(\mathrm{B}_{51}\right)$ for 1851 was published, but not the number of deaths $\left(\mathrm{D}_{51}\right)$. We thus estimated the latter, age by age, assuming the same infant mortality as that of 1852 : $\mathrm{D}_{51}=\mathrm{D}_{52} \mathrm{x}\left(\mathrm{B}_{51} / \mathrm{B}_{52}\right)$. A check using the cohort of 1852, focusing on the first year of life, gave reassuring results. Finally, 1851 data for Serbische Wojwodschaft und Temeser Banat include only the total of live births and stillbirths. This distinction is estimated using the same proportion found among the 1852 births.

Table 2: $\quad$ Data on births and deaths under the age of 3. Länder of the Austrian Empire, 1851-54

\begin{tabular}{|c|c|c|c|}
\hline $\mathbf{n}$ & KronLänder & Births $\left(^{*}\right)$ & Deaths aged 0-2 $\left(^{* *}\right)$ \\
\hline $\begin{array}{l}1 \mathrm{a} \\
1 \mathrm{~b}\end{array}$ & $\begin{array}{l}\text { Wien } \\
\text { Oesterreich unter der Enns }\end{array}$ & $\begin{array}{l}\text { Separate data for the city of } \\
\text { Wien only in } 1851-52\end{array}$ & No data for Wien in $1851-52$ \\
\hline 2 & Oesterreich ob der Enns & Complete & Complete \\
\hline 3 & Salzburg & Complete & Complete \\
\hline 4 & Steiermark & Complete & Complete \\
\hline 5 & Kärnthen & Complete & Complete \\
\hline 6 & Krain & Complete & Complete \\
\hline $\begin{array}{l}7 \mathrm{a} \\
7 \mathrm{~b}\end{array}$ & $\begin{array}{l}\text { Görz, Gradisca und Istrien } \\
\text { Triest sammt Gebiet }\end{array}$ & $\begin{array}{l}\text { Separate data for the city of } \\
\text { Triest only in } 1851\end{array}$ & $\begin{array}{l}\text { Separate data for the city of } \\
\text { Triest only in } 1851\end{array}$ \\
\hline 8 & Tirol und Vorarlberg & Complete & Complete \\
\hline 9 & Böhmen & Complete & Complete \\
\hline 10 & Mähren & Complete & Complete \\
\hline 11 & Schlesien & Complete & Complete \\
\hline 12 & Krakau sammt Gebiet & Complete & Complete \\
\hline 13 & Galizien & Complete & Complete \\
\hline 14 & Bukovina & Complete & Complete \\
\hline 15 & Dalmatien & Complete & No data for the four years \\
\hline 16 & Lombardie & Complete & No data in 1851 \\
\hline 17 & Venedig & Complete & No data in 1851 \\
\hline 18 & Ungern & Complete & Complete \\
\hline
\end{tabular}


Table 2: $\quad$ (Continued)

\begin{tabular}{|c|c|c|c|}
\hline $\mathbf{n}$ & KronLänder & Births $\left(^{*}\right)$ & Deaths aged 0-2 $\left({ }^{* *}\right)$ \\
\hline 19 & $\begin{array}{l}\text { Serbische Wojwodschaft und das } \\
\text { Temeser Banat }\end{array}$ & $\begin{array}{l}\text { Only total live births and } \\
\text { stillbirths by sex in } 1851 . \\
\text { Missing data for stillbirths in } \\
1853-54\end{array}$ & No data in 1851 \\
\hline 20 & Kroatien und Slavonien & $\begin{array}{l}\text { No data in } 1851 \text {; Only total } \\
\text { live births and stillbirths by } \\
\text { sex in } 1852-53\end{array}$ & No data in 1851-53 \\
\hline 21 & Siebenbürgen & Complete & Complete \\
\hline 22 & Militärgränze & Complete & Complete \\
\hline
\end{tabular}

Other authors have considered the demographic balance for years adjacent to the census in order to check the consistency of births, deaths, and census counts (Findl 1979; Ediev and Gisser 2007:338). Those works indicated that there was good coverage of births and deaths, but a sort of "shortage" of infants in census counts for the Austrian Alpenländer. We assess the coverage of the recorded data on births and deaths without considering census data, but using some simple devices. One is to verify whether the sex ratio, taking into account the large scale of the observations, varies significantly from a ratio of 105-106 male births for every 100 female births. This ratio hardly differs across human populations, independent of space and time. Higher values indicate a tendency to 'under-register' female infants. For the years under consideration, we observe little more than 106 males for every 100 females, for a total of about 1.4 million live births registered every year (Table 3 ). In several cases, this value shifts away from the reference ratio, although this occurs predominantly in the relatively small populations. In the more populous regions (Böhmen, Galizien, Ungern), the sex ratio is quite close to 106 .

The sex ratio at birth, $100 \mathrm{xM} / \mathrm{F}$, looks like a normal random variable, distributed all around the mean of 106. Consequently, it is possible to calculate the $95 \%$ confidence-interval that depends only on the number of births (Livi Bacci 1999:25-26) - the greater the number of the births, the narrower the interval (Table 3). The sex ratios fall outside the interval only three times: Krakau in 1853 (about 6,000 births every year), Dalmatien in 1854 (about 13,000 births), and Lombardie (106,000) (Figure 2). 
Table 3: $\quad$ Sex ratio for live births $(100 \cdot M / F)$. Länder of the Austrian Empire, 1851-54

\begin{tabular}{|c|c|c|c|c|c|c|}
\hline \multirow[b]{2}{*}{$\mathbf{n}$} & \multirow[b]{2}{*}{ KronLänder } & \multicolumn{2}{|l|}{ Births } & \multirow[b]{2}{*}{1852} & \multirow[b]{2}{*}{1853} & \multirow[b]{2}{*}{1854} \\
\hline & & in 1851 & 1851 & & & \\
\hline $1 \mathrm{a}$ & Wien & 21,191 & 104.1 & 105.3 & - & - \\
\hline $1 b$ & Oesterreich unter der Enns $\left({ }^{*}\right)$ & 40,162 & 104.8 & 107.3 & 104.3 & 105.1 \\
\hline 2 & Oesterreich ob der Enns & 20,964 & 102.7 & 104.8 & 107.8 & 105.9 \\
\hline 3 & Salzburg & 4,095 & 103.1 & 110.9 & 104.8 & 112.4 \\
\hline 4 & Steiermark & 29,982 & 103.8 & 106.3 & 105.4 & 104.7 \\
\hline 5 & Kärnthen & 9,297 & 106.8 & 106.9 & 106.1 & 107.4 \\
\hline 6 & Krain & 13,879 & 102.3 & 105.1 & 102.1 & 105.0 \\
\hline 7 & Triest,Görz, Gradisca, Istrien $\left(^{* *}\right)$ & 19,354 & 104.8 & 106.0 & 103.1 & 104.4 \\
\hline 8 & Tirol und Vorarlberg & 26,892 & 106.6 & 106.7 & 107.5 & 105.7 \\
\hline 9 & Böhmen & 187,335 & 106.8 & 106.8 & 106.3 & 105.3 \\
\hline 10 & Mähren & 77,019 & 105.4 & 106.4 & 106.1 & 106.2 \\
\hline 11 & Schlesien & 18,393 & 104.8 & 104.4 & 107.7 & 107.0 \\
\hline 12 & Krakau sammt Gebiet & 6,320 & 105.5 & 102.4 & 96.9 & 104.5 \\
\hline 13 & Galizien & 190,145 & 106.3 & 106.9 & 106.7 & 106.8 \\
\hline 14 & Bukovina & 12,839 & 105.9 & 107.6 & 108.0 & 103.9 \\
\hline 15 & Dalmatien & 12,994 & 109.2 & 106.8 & 106.9 & 96.8 \\
\hline 16 & Lombardie & 106,441 & 106.0 & 106.9 & 107.1 & 107.7 \\
\hline 17 & Venedig & 88,942 & 107.1 & 106.7 & 106.1 & 107.4 \\
\hline 18 & Ungern & 363,926 & 105.9 & 105.5 & 106.0 & 105.8 \\
\hline 19 & Serbische Woiwodschaft und Temeser Banat $\left(^{* * *}\right)$ & 68,191 & 106.3 & 104.7 & 105.1 & 106.8 \\
\hline 20 & Kroatien und Slavonien $(* * *)$ & 38,326 & - & 107.5 & 103.5 & 106.2 \\
\hline 21 & Siebenbürgen & 76,937 & 107.0 & 106.5 & 106.5 & 106.7 \\
\hline \multirow{2}{*}{22} & Militärgränze & 43,321 & 105.6 & 107.7 & 106.0 & 105.3 \\
\hline & Total Empire- & & 106.0 & 106.3 & 106.1 & 106.0 \\
\hline & \\
\hline$(* *)$ & \multirow{2}{*}{\multicolumn{6}{|c|}{$\begin{array}{l}\text { In } 1851 \text { Görz, Gradisca und Istrien } 104.9 \text { with } 15,135 \text { births; Triest } 104.5 \text { with } 4,219 \text { births. } \\
1851 \text { calculated on total live births and stillbirths. }\end{array}$}} \\
\hline$\left({ }^{* \star \star}\right)$ & & & & & & \\
\hline$\left({ }^{\star \star \star \star}\right)$ & \multicolumn{6}{|c|}{ ) 1852 and 1853 calculated on total live births and stillbirths (38,326 in 1852). } \\
\hline
\end{tabular}

Different considerations arise with regard to the completeness and quality of the information on stillbirths (Table 4). The results indicate that stillbirths represented about $1.5 \%$ of total births (live births plus stillbirths), a low percentage when compared to countries with analogous levels of infant mortality. For example, in Italy the proportion of stillbirths was $2.2 \%$ in $1861-1870,2.9 \%$ in $1871-1880,3.5 \%$ in 1881 1890 , and $4.0 \%$ in $1891-1900$ (Istat 1976). During the same period, infant mortality dropped from $226 \%$ o (1861-1870) to $176 \%$ (1891-1900). The large degree of variability 
among Länder also suggests that the registering criteria were not entirely homogeneous. Nonetheless, understanding the direction of these differences is not simple given that with the Länder considered as statistical units - the territorial correlation between stillbirths and mortality in the first month of life is next to zero. The sex ratio, on the other hand, is closer to 'normal' (136 male stillbirths for every 100 female stillbirths), and is similar to ratios seen in other contexts during this period (an average of 134 in Italy during 1861-1900, Istat 1976), as is the higher percentage of illegitimate infants among stillbirths (18.5\%) than among live births $(8.3 \%)$.

Figure 2: Sex ratio at birth $(100 \times \mathrm{M} / \mathrm{F})$ by number of births and $95 \%$ confidence intervals. Länder of the Austrian Empire, 1851-54

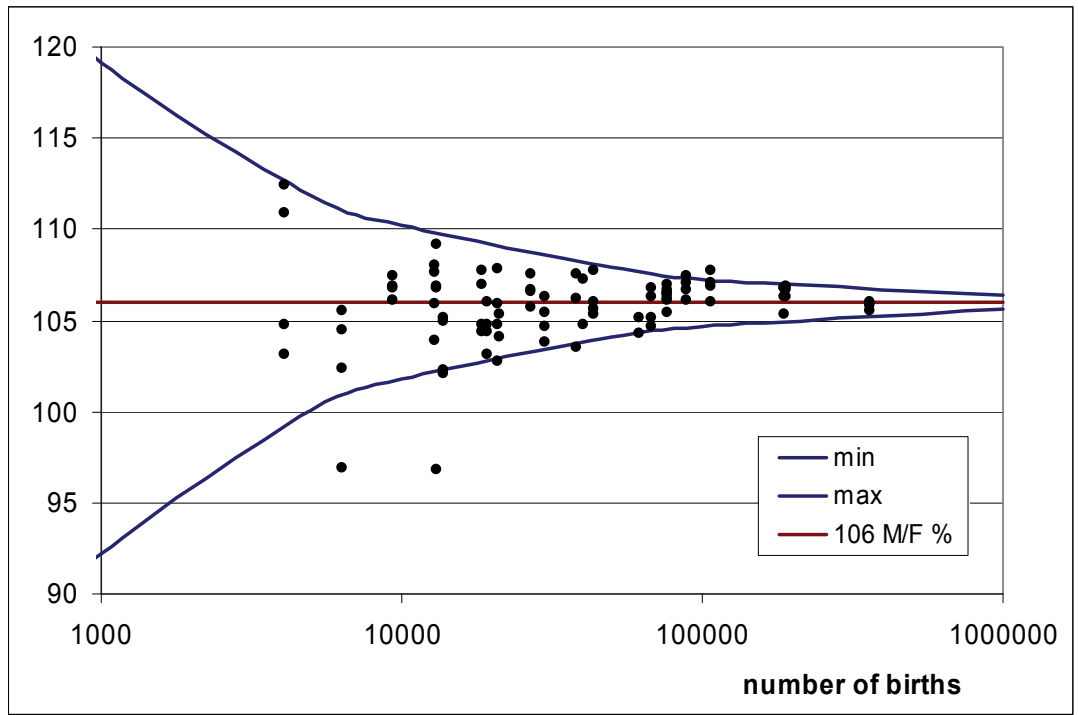

Nominative surveys of this data for two parishes (Agna and Casalserugo), both located in the province of Padua (in Venedig), reveal that different criteria were employed for registering stillbirths during the period 1821-1866 (Dalla-Zuanna and Rosina 2008). In Agna, the priest recorded the deaths of unbaptised children as stillbirths. In Casalserugo, stillbirths were simply not recorded, and the number of baptisms in the canonical register is the same as the number of births in the civil register. Such differences suggest that caution should be used when considering this 
sort of data. In constructing the life table, we chose not to consider stillbirths, and henceforth estimates of infant mortality indictors are based on live births.

Table 4: Stillbirths: proportion and sex ratio.

\section{Länder of the Austrian Empire, 1851-54}

\begin{tabular}{|c|c|c|c|c|c|}
\hline \multirow{2}{*}{ KronLänder } & \multicolumn{4}{|c|}{$\begin{array}{l}\text { Stillbirths on the sum of live } \\
\text { births and stillbirths (\%) }\end{array}$} & \multirow{2}{*}{$\begin{array}{c}\% \mathrm{M} / \mathrm{F} \\
\text { (stillbirths) } \\
\text { Average } \\
1851-54 \\
\end{array}$} \\
\hline & 1851 & 1852 & 1853 & 1854 & \\
\hline Wien & 4.1 & 4.3 & - & - & 129.4 \\
\hline Oesterreich unter der Enns $\left(^{*}\right)$ & 2.5 & 2.2 & 2.8 & 3.1 & 127.6 \\
\hline Oesterreich ob der Enns & 2.1 & 2.1 & 2.2 & 2.2 & 127.5 \\
\hline Salzburg & 1.7 & 1.6 & 1.9 & 1.8 & 151.1 \\
\hline Steiermark & 2.3 & 2.4 & 2.3 & 2.5 & 124.8 \\
\hline Kärnthen & 1.2 & 1.6 & 1.9 & 1.6 & 133.4 \\
\hline Krain & 1.4 & 1.5 & 1.6 & 1.5 & 137.2 \\
\hline Triest, Görz, Gradisca, Istrien $\left(^{* \star}\right)$ & 2.1 & 2.4 & 2.3 & 2.5 & 139.7 \\
\hline Tirol und Vorarlberg & 1.1 & 1.0 & 0.9 & 0.9 & 171.9 \\
\hline Böhmen & 2.4 & 2.4 & 2.3 & 2.3 & 129.1 \\
\hline Mähren & 1.5 & 1.7 & 1.8 & 1.6 & 128.4 \\
\hline Schlesien & 2.0 & 2.4 & 2.1 & 1.8 & 130.0 \\
\hline Galizien & 1.2 & 1.4 & 1.4 & 1.4 & 138.4 \\
\hline Krakau sammt Gebiet & 2.2 & 2.2 & 2.1 & 1.9 & 142.0 \\
\hline Bukovina & 0.3 & 1.0 & 1.1 & 1.0 & 160.1 \\
\hline Dalmatien & 0.3 & 0.1 & 0.1 & 0.3 & 144.5 \\
\hline Lombardie & 1.3 & 1.7 & 1.8 & 1.7 & 167.2 \\
\hline Venedig & 1.1 & 1.6 & 1.5 & 1.3 & 169.6 \\
\hline Ungern & 1.0 & 1.2 & 1.1 & 1.2 & 132.0 \\
\hline Siebenbürgen & 0.8 & 1.1 & 0.9 & 0.9 & 131.5 \\
\hline Militärgränze & 0.9 & 1.3 & 1.3 & 1.4 & 134.6 \\
\hline Serbische Woiwodschaft und Temeser Banat & - & 0.6 & - & - & 131.1 \\
\hline Kroatien und Slavonien & - & - & - & 0.7 & 136.2 \\
\hline Total Empire & 1.4 & 1.6 & 1.5 & 1.5 & 136.2 \\
\hline
\end{tabular}

(*) 1853 and 1854 Wien included.

$\left.{ }^{* *}\right)$ In 1851 Görz, Gradisca und Istrien 1.3; Triest 4.8. 
In the Tafeln, births are systematically differentiated by legitimacy (Table 5). Variability between regions is substantial, ranging from over 50\% illegitimate births in Vienna (this indicator decreases to $26 \%$ when considering the entire territory of Oesterreich unter der Enns), to only 1\%-3\% in several of the eastern and southern Austrian Empire Länder (Dalmatien, Militärgränze, Serbische Wojwodschaft und Temeser Banat, Venedig). Finally, in 1851, it is possible to observe the difference between Triest (21.9\%) and its territory (Görz, Gradisca, Istrien: 2.6\%); in the years that followed, however, the data are combined. The high levels observed in Vienna and Trieste may be related to the urban concentration of foundling institutes. More generally, the considerable differences between groups of Länder may be due to different legislation governing marriage. In places where the percentage of illegitimate births is systematically higher - for the most part, German-speaking Länder located in the area which, after 1918, became the Republic of Austria - there were strong legal restrictions on marriage for the poor (Prioux 1993; for Tirol-Vorarlbelg, and mainly the county of Trento, see also Grandi 1995). With regard to legitimacy levels, three groups of Länder can be identified, revealing a certain degree of territorial continuity (Figure $3)$ : high level of illegitimacy (20\% or higher during 1851-1854): Oesterreich unter der Enns, Oesterreich ob der Enns, Salzburg, Steiermark, and Kärnthen; medium (5\%20\%): Krain, Görz Gradisca und Istrien Triest sammt Gebiet, Tirol und Vorarlberg, Böhmen, Mähren, Schlesien, Krakau sammt Gebiet, Galizien, and Bukovina; and low (5\% or lower): Dalmatien, Lombardie, Venedig, Ungern, Serbische Woiwodschaft und Temeser Banat, Kroatien und Slavonien, Siebenbürgen, and Militärgränze.

Table 5: Illegitimacy by vitality (\% illegitimate births). Länder of the Austrian Empire, 1851-54

\begin{tabular}{lrrrrc}
\hline & \multicolumn{3}{c}{ Live births } & \multicolumn{3}{c}{ Stillbirths } \\
\cline { 2 - 6 } KronLänder & $\mathbf{1 8 5 1}$ & $\mathbf{1 8 5 2}$ & $\mathbf{1 8 5 3}$ & $\mathbf{1 8 5 4}$ & $\mathbf{1 8 5 1 - 5 4}$ \\
\hline Wien & 51.7 & 50.5 & - & - & 56.7 \\
Oesterreich unter der Enns $\left(^{*}\right)$ & 15.7 & 15.0 & 26.7 & 26.6 & 30.3 \\
Oesterreich ob der Enns & 19.3 & 19.8 & 20.7 & 21.4 & 26.0 \\
Salzburg & 25.2 & 24.0 & 24.3 & 25.2 & 36.7 \\
Steiermark & 25.6 & 24.8 & 26.0 & 26.7 & 36.6 \\
Kärnthen & 34.4 & 35.4 & 36.4 & 36.9 & 48.1 \\
Krain & 8.4 & 7.6 & 8.7 & 8.8 & 17.7 \\
Triest, Görz, Gradisca, Istrien $\left(^{* *}\right)$ & 6.8 & 7.0 & 7.7 & 8.5 & 15.0 \\
Tirol und Vorarlberg & 6.9 & 4.6 & 4.6 & 4.9 & 11.7 \\
Böhmen & 14.3 & 14.1 & 13.5 & 14.1 & 22.4 \\
\hline
\end{tabular}


Dalla-Zuanna \& Rossi: Comparisons of infant mortality, Austrian Empire 1851-54

Table 5: (Continued)

\begin{tabular}{lrrrrr}
\hline & \multicolumn{3}{c}{ Live births } & \multicolumn{2}{c}{ Stillbirths } \\
\cline { 2 - 6 } KronLänder & $\mathbf{1 8 5 1}$ & $\mathbf{1 8 5 2}$ & $\mathbf{1 8 5 3}$ & $\mathbf{1 8 5 4}$ & $\mathbf{1 8 5 1 - 5 4}$ \\
\hline Mähren & 13.3 & 12.8 & 12.7 & 13.2 & 25.5 \\
Schlesien & 13.1 & 13.8 & 13.2 & 13.4 & 18.7 \\
Galizien & 8.3 & 7.5 & 7.3 & 7.5 & 16.4 \\
Krakau sammt Gebiet & 11.6 & 11.7 & 12.3 & 11.6 & 20.3 \\
Bukovina & 7.6 & 6.6 & 8.0 & 7.0 & 9.3 \\
Dalmatien & 3.3 & 3.1 & 2.3 & 1.8 & 32.5 \\
Lombardie & 4.5 & 2.8 & 3.1 & 3.8 & 10.7 \\
Venedig & 2.6 & 2.9 & 3.1 & 3.2 & 9.0 \\
Ungern & 4.3 & 4.1 & 4.1 & 4.3 & 9.2 \\
Siebenbürgen & 3.2 & 3.0 & 3.3 & 4.0 & 9.9 \\
Militärgränze & 1.6 & 1.5 & 1.4 & 1.3 & 3.4 \\
Serbische Woiwodschaft und Temeser Banat & - & 1.7 & 1.7 & 1.9 & 4.5 \\
Kroatien und Slavonien & - & - & - & 4.2 & 10.6 \\
Total Empire & 8.8 & 7.9 & 8.0 & 8.4 & 18.5 \\
\hline
\end{tabular}

$\left(^{*}\right) 1853$ and 1854 Wien included.

$\left.{ }^{(*}\right)$ In 1851, respectively on live births and on still births: Görz, Gradisca und Istrien 2.6 and 5.0; Triest 21.9 and 37.2.

Figure 3: Illegitimacy in the Länder of Austrian Empire, mean 1851-54

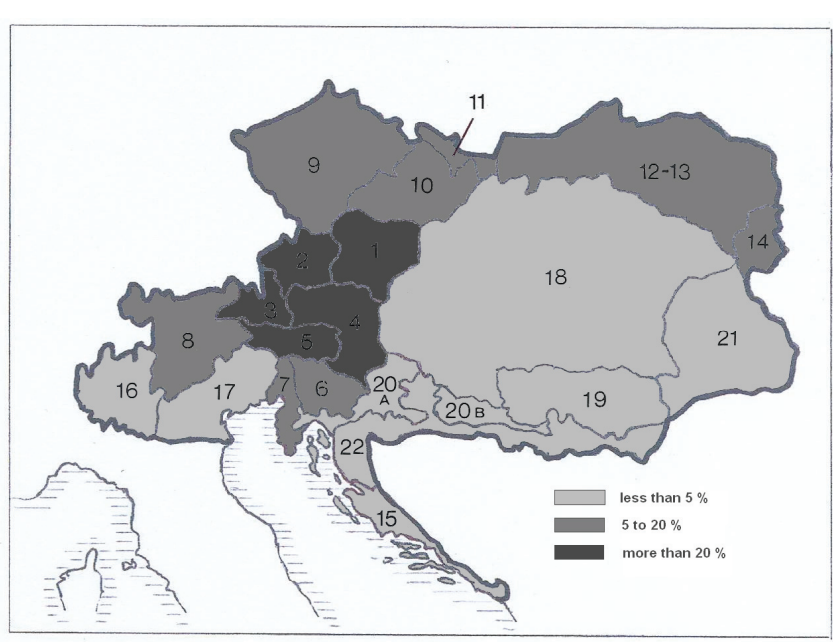

\begin{tabular}{|c|l|}
\hline $\mathbf{n}$ & Länder \\
\hline 1 & Oesterreich unter der Enns \\
2 & Oesterreich ob der Enns \\
3 & Salzburg \\
4 & Steiermark \\
5 & Kärnthen \\
6 & Krain \\
7 & Görz, Gradisca, Istrien, Triest \\
& sammt Gebiet (Kustenland) \\
8 & Tirol und Vorarlberg \\
9 & Böhmen \\
10 & Mähren \\
11 & Schlesien \\
$13-12$ & Galizien und Krakau \\
14 & Bukowina \\
15 & Dalmatien \\
16 & Lombardie \\
17 & Venedig \\
18 & Ungern \\
19 & Serbische Wojwodschaft \\
& und Temeser Banat \\
20 & Kroatien (A) und Slavonien (B) \\
21 & Siebenbürgen \\
22 & Militärgränze \\
\hline
\end{tabular}


With regard to deaths, one way of evaluating the quality of the registers is to examine the quota of death acts lacking any indication of age. For the period of 18511854, the Tafeln include the distribution of deaths by single annual ages for each Land, including additional details (as described above) for ages up to three. Death acts lacking any indication of age are quite rare: $0.11 \%$ in the period $1851-1854$, when considering the Empire as a whole. Unknown to us, however, is whether this low level (so low as to raise some suspicion) can be linked to a corrective system applied to non-responses of age existent at the local or administrative level.

Another way of evaluating the quality of the data on deaths is to estimate any possible rounding of the age at death recorded on the act. As mentioned above, data on death during the first year of life in the Tafeln are classified by month for the first three months, and then by trimester for the ages that follow. It is, consequently, not possible to conduct a detailed analysis specific to the exact number of months. That said, several results from other studies concerning the first year of life should be mentioned. For example, Ediev (2003), in his work on 1897 Russia, observed a strong attraction to six months in the classification of children less than a year old by single month of age. A similar attraction to six months is present in several parishes of Venedig during the 17th and 18th centuries - albeit to a much lesser degree than is reported in Ediev's results. The attraction then progressively lessens and then disappears in the 19th century (Rossi and Tesolat 2006).

An additional consideration, useful when reflecting on the results in the infant mortality table, concerns age-heaping at several adult ages. Deaths by ages 5-94 in each of the Länder in the year 1852 were grouped according to the last digit: the frequency of each digit should not, therefore, be much more than 10\% (Table 6 and Figure 4). Age-heaping at ages that end in 0 and 5, which is most commonly observed, is quite contained: it exceeds $13 \%$ in only one region for ages ending in 0 , and in two regions for ages ending in 5, without any notable differences by sex. However, in a number of regions (Schlesien, Krakau sammt Gebiet, Galizien, Bukovina, Ungern, Serbische Woiwodschaft und Temeser Banat, Siebenbürgen and Militärgränze), there is an attraction to ages that end in 9 (with a frequency near or higher than 13\%); in one region, the frequency is also slightly elevated for ages that end in 6. However, these minimally elevated percentages concern only the eastern regions of the Empire (death by age are not available for Kroatien und Slavonien). It is not easy to interpret the significance of this result in the absence of information both relative to criteria used when passing from single to aggregated data, and the criteria used in the age classification. In this specific case, there may be a classification issue concerning age at last birthday (complete years), as opposed to age at next birthday (years begun). In other words, in these regions the actual attraction could be on years begun, which end in 0 (for example, 30), then classified as complete years, which end in 9 (for example, 29). 
Further considerations concerning the quality of the data will be presented after we have estimated the probabilities of death and the life table, and compared infant mortality at different ages and by sex across the Länder.

Table 6: Frequencies of last digit in death ages 5-94. Länder of the Austrian Empire, 1852

\begin{tabular}{|c|c|c|c|c|c|c|c|c|c|c|c|c|c|}
\hline \multirow[b]{2}{*}{$\mathbf{n}$} & \multirow[b]{2}{*}{ KronLänder } & \multicolumn{11}{|c|}{ Ages ending in } & \multirow{2}{*}{$\begin{array}{c}\text { Averages of } \\
\text { differences } \\
\text { from } 10 \% \\
\text { (abs. value) }\end{array}$} \\
\hline & & 5 & 6 & 7 & 8 & 9 & 0 & 1 & 2 & 3 & 4 & total & \\
\hline 1 & Oesterreich unter der Enns & 11.2 & 10.3 & 10.0 & 9.8 & 9.6 & 10.8 & 9.3 & 10.2 & 9.0 & 9.7 & 100.0 & 0.51 \\
\hline 2 & Oesterreich ob der Enns & 10.6 & 10.2 & 9.9 & 10.1 & 9.4 & 10.8 & 9.5 & 10.3 & 9.4 & 9.8 & 100.0 & 0.40 \\
\hline 3 & Salzburg & 10.3 & 10.0 & 9.5 & 11.8 & 8.2 & 13.9 & 8.0 & 10.9 & 9.0 & 8.4 & 100.0 & 1.38 \\
\hline 4 & Steiermark & 10.9 & 9.7 & 9.7 & 8.8 & 11.3 & 12.1 & 9.5 & 9.9 & 8.3 & 9.9 & 100.0 & 0.85 \\
\hline 5 & Kärnthen & 10.8 & 9.8 & 8.8 & 10.3 & 10.7 & 12.2 & 7.8 & 10.5 & 9.0 & 10.1 & 100.0 & 0.92 \\
\hline 6 & Krain & 11.3 & 10.8 & 10.4 & 9.6 & 10.8 & 10.6 & 9.7 & 9.5 & 8.8 & 8.5 & 100.0 & 0.79 \\
\hline 7 & $\begin{array}{l}\text { Görz, Gradisca und Istrien, } \\
\text { Triest sammt Gebiet }\end{array}$ & 11.3 & 10.4 & 10.0 & 9.5 & 11.3 & 11.2 & 9.8 & 8.9 & 8.3 & 9.1 & 100.0 & 0.85 \\
\hline 8 & Tirol und Vorarlberg & 11.0 & 10.5 & 10.3 & 10.0 & 8.8 & 11.4 & 8.8 & 10.5 & 9.0 & 9.7 & 100.0 & 0.75 \\
\hline 9 & Böhmen & 11.8 & 10.3 & 9.8 & 9.1 & 10.4 & 12.5 & 8.5 & 9.8 & 8.3 & 9.5 & 100.0 & 1.00 \\
\hline 10 & Mähren & 12.0 & 10.2 & 10.5 & 9.0 & 11.4 & 10.9 & 8.8 & 9.6 & 8.1 & 9.5 & 100.0 & 0.99 \\
\hline 11 & Schlesien & 11.9 & 9.8 & 10.4 & 9.1 & 13.3 & 10.8 & 8.4 & 8.5 & 8.4 & 9.5 & 100.0 & 1.28 \\
\hline 12 & Krakau sammt Gebiet & 11.3 & 9.6 & 10.2 & 9.1 & 14.8 & 10.9 & 9.5 & 8.0 & 7.7 & 8.9 & 100.0 & 1.43 \\
\hline 13 & Galizien & 12.3 & 10.3 & 9.6 & 7.1 & 19.7 & 10.0 & 8.1 & 7.6 & 7.2 & 8.1 & 100.0 & 2.45 \\
\hline 14 & Bukovina & 16.3 & 13.8 & 7.8 & 7.9 & 13.8 & 9.7 & 6.8 & 6.7 & 7.1 & 10.0 & 100.0 & 2.79 \\
\hline 16 & Lombardie & 11.0 & 10.7 & 9.9 & 9.4 & 9.5 & 12.5 & 9.1 & 9.8 & 8.8 & 9.5 & 100.0 & 0.83 \\
\hline 17 & Venedig & 10.9 & 10.5 & 10.3 & 9.5 & 9.5 & 10.8 & 9.8 & 9.9 & 9.0 & 9.8 & 100.0 & 0.50 \\
\hline 18 & Ungern & 13.0 & 10.7 & 10.4 & 8.6 & 12.6 & 10.7 & 8.6 & 8.4 & 7.7 & 9.3 & 100.0 & 1.50 \\
\hline 19 & $\begin{array}{l}\text { Serbische Wojwodschaft } \\
\text { und Temeser Banat }\end{array}$ & 12.9 & 10.2 & 10.4 & 8.4 & 13.3 & 10.8 & 9.5 & 8.5 & 7.1 & 8.9 & 100.0 & 1.52 \\
\hline 21 & Siebenbürgen & 12.2 & 8.0 & 10.1 & 7.2 & 17.5 & 10.0 & 10.0 & 7.2 & 7.4 & 10.3 & 100.0 & 2.03 \\
\hline 22 & Militärgränze & 12.8 & 9.4 & 9.7 & 7.8 & 19.4 & 11.2 & 7.4 & 6.6 & 6.3 & 9.5 & 100.0 & 2.68 \\
\hline & Total $\left(^{*}\right)$ & 11.9 & 10.1 & 10.1 & 8.9 & 12.5 & 11.2 & 9.0 & 8.8 & 8.0 & 9.4 & 100.0 & 1.16 \\
\hline & Total Males & 11.9 & 10.3 & 10.2 & 9.1 & 12.1 & 10.9 & 9.2 & 8.9 & 8.1 & 9.3 & 100.0 & 1.08 \\
\hline & Total Females & 11.9 & 10.0 & 10.0 & 8.8 & 12.9 & 11.4 & 8.9 & 8.7 & 7.9 & 9.5 & 100.0 & 1.24 \\
\hline
\end{tabular}

$(*)$ For Dalmatien and Kroatien und Slavonien classification by single age of death is not reported. 
Figure 4: $\quad$ Percent of last digit in death ages 5-94.

Länder of the Austrian Empire, 1852

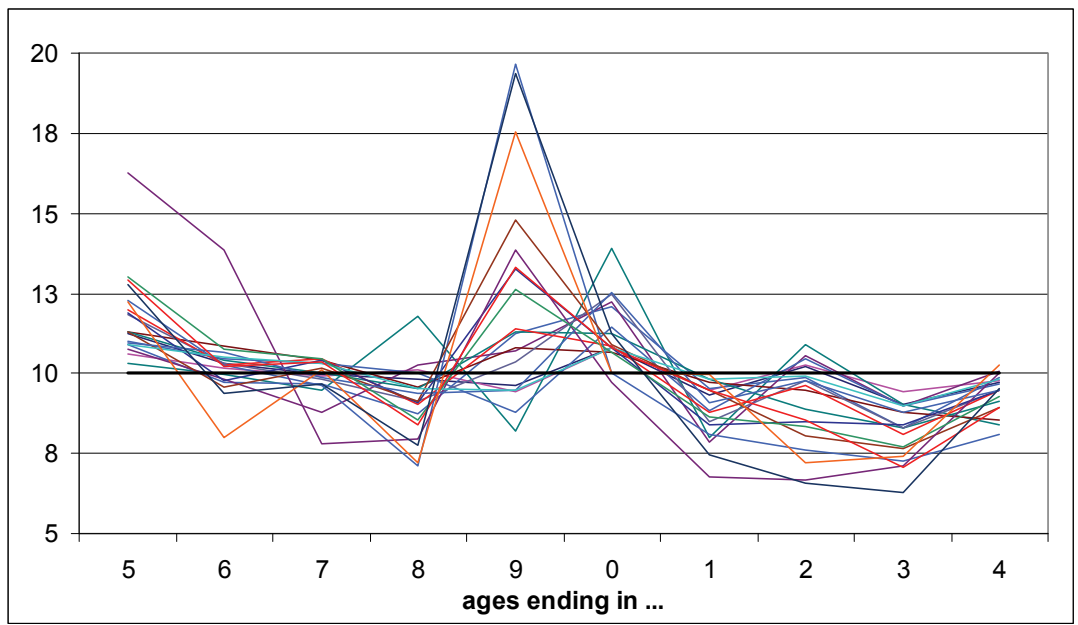

\section{Life tables for ages 0-3 for the cohort born in 1851}

Complete data on deaths by the nine ages marking the first three years of life are available for the years 1851-1854. Consequently, it is possible to build a life table up until the third birthday for the cohort born in 1851 by means of some approximations (Figures 5 and 6). More specifically, the Tafeln include:

For the first year of life:

- Deaths in the first month of life in 1851 and 1852;

- Deaths in the second month of life in 1851 and 1852;

- Deaths in the third month of life in 1851 and 1852;

- Deaths in the $4^{\text {th }}, 5^{\text {th }}$ and $6^{\text {th }}$ months of life in 1851 and 1852 ;

- Deaths in the $7^{\text {th }}, 8^{\text {th }}$ and $9^{\text {th }}$ months of life in 1851 and 1852 ;

- Deaths in the $10^{\text {th }}, 11^{\text {th }}$ and $12^{\text {th }}$ months of life in 1851 and 1852;

For the second year of life:

- Deaths between the $13^{\text {th }}$ and $18^{\text {th }}$ months of life in 1852 and 1853 ;

- Deaths between the $19^{\text {th }}$ and $24^{\text {th }}$ months of life in 1852 and 1853 . 
The data are not, however, organised by cohort (parallelogram in Figures 5 and 6), but rather by period (rectangles). To calculate the life table for the cohort born in 1851, deaths by year at birth and age (parallelograms) must be estimated, starting from deaths by year at death and age (rectangles).

Figure 5: Lexis's scheme for life tables at ages 0-3 in the Länder of the Austrian Empire. Birth cohort 1851

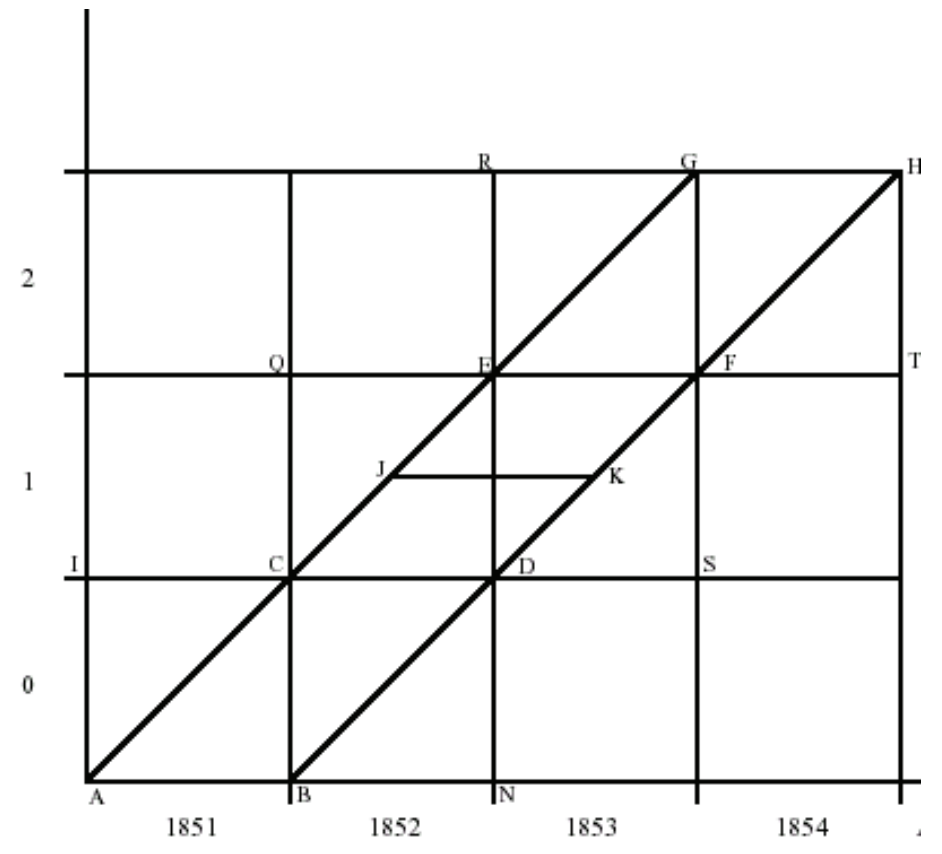


Figure 6: Lexis's scheme for life tables at ages 0-11 months in the Länder of the Austrian Empire. Birth cohort 1851

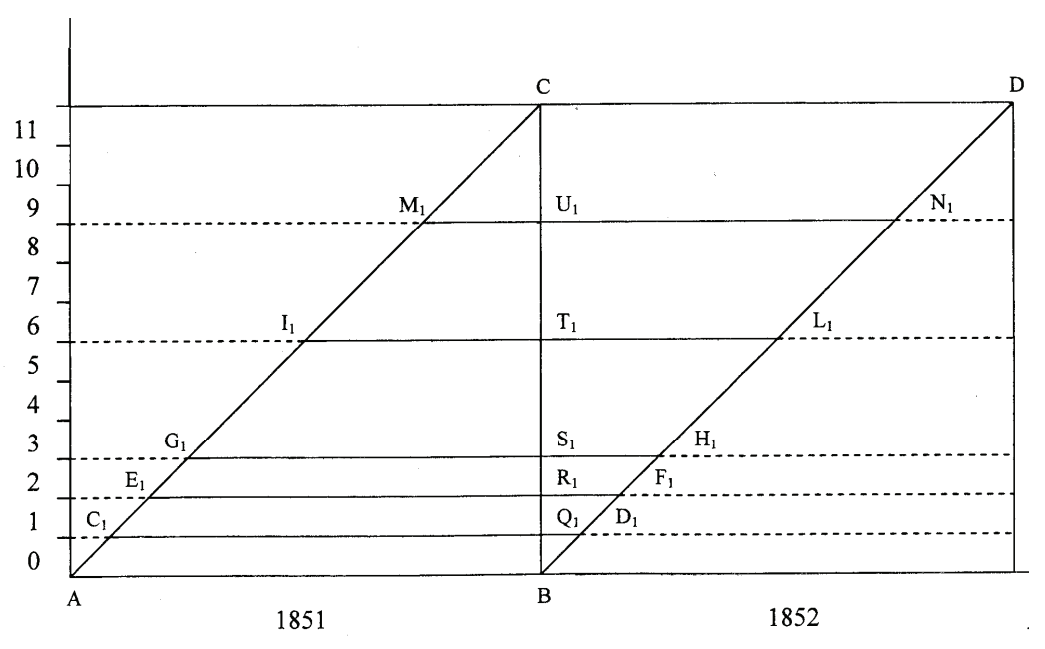

As data are detailed by month (for the first three months of life), quarterly (until the first birthday), bi-yearly until the second birthday, and annually for the third year of life, it is not too rash to suppose that deaths are equally distributed into each of these age classes. Under this hypothesis, it is a simple matter to estimate for each age the number of deaths belonging to the cohort born in 1851. The deaths during the first month for those born in 1851 are estimated as the sum of 23/24 of the deaths which occurred during the first month registered in 1851, and 1/24 of the deaths registered during the first month of 1852. In Figure 6, these two addenda are the trapezium $\mathrm{AC} 1 \mathrm{Q} 1 \mathrm{~B}$ and the triangle $\mathrm{BQ} 1 \mathrm{D} 1$, which are composed in the parallelogram $\mathrm{AC} 1 \mathrm{D} 1 \mathrm{~B}$. This method is similarly employed for the other ages, changing the proportions as follows:

Deaths in the $2^{\text {nd }}$ month of life, for those born in 1851:

$\mathrm{C} 1 \mathrm{E} 1 \mathrm{~F} 1 \mathrm{D} 1=21 / 24 \times$ Deaths in $2^{\text {nd }}$ month registered in $1851+$ $+3 / 24 \times$ Deaths in $2^{\text {nd }}$ month registered in 1852 ;

Deaths in the $3^{\text {rd }}$ month of life, for those born in 1851:

$\mathrm{E} 1 \mathrm{G} 1 \mathrm{H} 1 \mathrm{~F} 1=19 / 24 \times$ Deaths in $3^{\text {rd }}$ month registered in $1851+$ $+5 / 24 \times$ Deaths in $3^{\text {rd }}$ month registered in 1852 ; 
Deaths in the $4^{\text {th }}, 5^{\text {th }}$, and $6^{\text {th }}$ months of life, for those born in 1851:

G1I1L1M1 $=45 / 72 \times$ Deaths in $4^{\text {th }}, 5^{\text {th }}, 6^{\text {th }}$ months registered in $1851+$ $+27 / 72 \times$ Deaths in $4^{\text {th }}, 5^{\text {th }}, 6^{\text {th }}$ month registered in 1852 ;

Deaths in the $7^{\text {th }}, 8^{\text {th }}$, and $9^{\text {th }}$ months of life, for those born in 1851:

$\mathrm{I} 1 \mathrm{M} 1 \mathrm{~N} 1 \mathrm{~L} 1=27 / 72 \times$ Deaths in $7^{\text {th }}, 8^{\text {th }}, 9^{\text {th }}$ months registered in $1851+$ $+45 / 72 \times$ Deaths in $7^{\text {th }}, 8^{\text {th }}, 9^{\text {th }}$ months registered in 1852 ;

Deaths in the $10^{\text {th }}, 11^{\text {th }}$, and $12^{\text {th }}$ month of life, for those born in 1851:

$\mathrm{M}_{1} \mathrm{CDN}_{1}=9 / 72 \times$ Deaths in $10^{\text {th }}, 11^{\text {th }}, 12^{\text {th }}$ months registered in $1851+$

$+63 / 72 \times$ Deaths in $10^{\text {th }}, 11^{\text {th }}, 12^{\text {th }}$ months registered in 1852 ;

And in Figure 5:

Deaths in the $13^{\text {th }}-18^{\text {th }}$ month of life, for those born in 1851:

$\mathrm{CJKD}=108 / 144 \times$ Deaths in $13^{\text {th }}-18^{\text {th }}$ months registered in $1852+$ $+36 / 144 \times$ Deaths in $13^{\text {th }}-18^{\text {th }}$ months registered in 1853 ;

Deaths in the $19^{\text {th }}-24^{\text {th }}$ month of life, for those born in 1851:

JEFK $=36 / 144 \times$ Deaths in $19^{\text {th }}-24^{\text {th }}$ months registered in $1852+$ $+108 / 144 \times$ Deaths in $19^{\text {th }}-24^{\text {th }}$ months registered in 1853 ;

Deaths in the third year of life, for those born in 1851:

$\mathrm{EGHF}=1 / 2 \times$ Deaths in $3^{\text {rd }}$ year registered in $1853+$ $+1 / 2 \times$ Deaths in $3^{\text {rd }}$ year registered in 1854

The live births in 1851 still surviving at each exact age $\mathrm{x}\left(\mathrm{S}_{\mathrm{x}}\right)$ are calculated as: $S_{x+1}=S_{x}-D_{x}$. For the first month of life (Figure 5): $C_{1} D_{1}=A B-A C_{1} D_{1} B$, for the second month: $\mathrm{E}_{1} \mathrm{~F}_{1}=\mathrm{C}_{1} \mathrm{D}_{1}-\mathrm{C}_{1} \mathrm{E}_{1} \mathrm{~F}_{1} \mathrm{D}_{1}$ etc.

The probabilities of death are calculated as $\mathrm{q}_{\mathrm{x}}=\mathrm{D}_{\mathrm{x}} / \mathrm{S}_{\mathrm{x}}$.

For the first month of life (Figure 6): $\mathrm{q}_{1 \text { st month }}=\mathrm{q}_{0}=\left(A C_{1} \mathrm{D}_{1} \mathrm{~B}\right) / \mathrm{AB}$; for the second month: $\mathrm{q}_{2 \text { nd month }}=\mathrm{q}_{1}=\left(\mathrm{AC}_{1} \mathrm{D}_{1} \mathrm{~B}\right) / \mathrm{AB}$, etc.

Some distortions could come from migrations, as some children could be born in one region, and die in another. However, each Land is large enough to suggest that this problem should not be too important.

Table 7 contains these probabilities, indicated in months: ${ }_{n} q_{x}$ is thus the probability for a survivor at exactly $\mathrm{x}$ months of dying before having turned $\mathrm{x}+\mathrm{n}$ months. Using this series of probabilities (Table 7), we calculate the life table for the first three years of life, starting from $1_{0}=100,000$ : deaths $\mathrm{d}_{\mathrm{x}}=\left(\mathrm{l}_{\mathrm{x}} \times \mathrm{q}_{\mathrm{x}}\right)$ and survivals $\left(\mathrm{l}_{\mathrm{x}+1}\right)=\mathrm{l}_{\mathrm{x}}-\mathrm{d}_{\mathrm{x}}$ (Tables 9 
and 10). Table 8 contains the index numbers of death probability $\mathrm{q}_{\mathrm{x}}$ presented in Table 7 (total Austrian Empire=100). Finally, Table 11 reports annual probabilities $\mathrm{q}_{0}, \mathrm{q}_{1}, \mathrm{q}_{2}$, and the three years of probabilities ${ }_{3} \mathrm{q}_{0}$.

Given that the population numbers in some Länder are relatively low, death probabilities (and, consequently, all of the parameters of the life table) are influenced by random variation. To address this issue, we calculated for the less populous Länder the confidence intervals at $5 \%$ for the death probabilities $\mathrm{q}_{\mathrm{x}}$ :

$$
\mathrm{q}_{\mathrm{x}} \pm 1.96 \sqrt{\frac{\mathrm{q}_{\mathrm{x}}\left(1-\mathrm{q}_{\mathrm{x}}\right)}{N_{x}}}
$$

where $\mathrm{N}_{\mathrm{x}}$ is the number of people exposed to death, i.e., the denominator of $\mathrm{q}_{\mathrm{x}}$ (Table 12). Even in the least populated region (Salzburg), the confidence interval for $\mathrm{q}_{0}$ (first month of life) is large enough to allow for reasonable comparisons between Länder. Several issues arise for the ages which follow, as the intervals widen in a relative measure. However, for Karnthen the confidence intervals for all ages are narrow enough. Consequently, for the other Länder, the death probabilities at each age are only marginally influenced by the random variation. 
Table 7: Life tables for the first 36 months of life. Cohort born in 1851 in the Länder of the Austrian Empire. Death probability $\left(1,000 \mathrm{x}_{\mathrm{n}} \mathbf{q}_{\mathrm{x}}\right)$

\begin{tabular}{|c|c|c|c|c|c|c|c|c|c|c|}
\hline \multirow[b]{3}{*}{$\mathbf{n}$} & \multirow[b]{3}{*}{ KronLänder } & \multicolumn{9}{|c|}{ Age (months) } \\
\hline & & \multicolumn{3}{|c|}{ Monthly probability } & \multicolumn{3}{|c|}{ Quarterly probability } & \multicolumn{2}{|c|}{$\begin{array}{c}\text { Biyearly } \\
\text { probability }\end{array}$} & \multirow{2}{*}{$\begin{array}{c}\begin{array}{c}\text { Annual } \\
\text { probability }\end{array} \\
{ }_{12} q_{24} \\
(24-35)\end{array}$} \\
\hline & & $\begin{array}{l}q_{0} \\
(0)\end{array}$ & $\begin{array}{l}q_{1} \\
(1)\end{array}$ & $\begin{array}{l}q_{2} \\
(2)\end{array}$ & $\begin{array}{c}{ }_{3} q_{3} \\
(3-5)\end{array}$ & $\begin{array}{c}{ }_{3} q_{6} \\
(6-8)\end{array}$ & $\begin{array}{c}{ }_{3} \mathrm{q9}_{9} \\
(9-11)\end{array}$ & $\begin{array}{c}{ }_{6} q_{12} \\
(12-17)\end{array}$ & $\begin{array}{c}{ }_{6} \mathrm{q}_{18} \\
(18-23)\end{array}$ & \\
\hline 1 & Oesterreich unter der Enns & 169.8 & 54.3 & 44.1 & 82.1 & 54.0 & 45.6 & - & - & - \\
\hline 2 & Oesterreich ob der Enns & 126.6 & 35.2 & 32.6 & 56.3 & 32.2 & 25.8 & 36.1 & 20.8 & 38.9 \\
\hline 3 & Salzburg & 141.9 & 33.5 & 29.7 & 56.7 & 40.9 & 29.3 & 38.8 & 15.9 & 19.5 \\
\hline 4 & Steiermark & 111.8 & 31.9 & 26.6 & 43.9 & 28.4 & 24.9 & 38.3 & 19.4 & 31.3 \\
\hline 5 & Kärnthen & 121.0 & 24.4 & 21.6 & 37.5 & 25.5 & 20.7 & 27.5 & 11.9 & 23.2 \\
\hline 6 & Krain & 70.9 & 17.2 & 13.9 & 27.8 & 22.3 & 26.7 & 41.6 & 26.5 & 50.9 \\
\hline 7 & $\begin{array}{l}\text { Görz, Gradisca und Istrien, Triest sammt } \\
\text { Gebiet }\end{array}$ & 105.9 & 21.4 & 17.2 & 27.9 & 29.1 & 36.6 & 55.8 & 37.5 & 52.1 \\
\hline 8 & Tirol und Vorarlberg & 130.0 & 20.7 & 17.4 & 33.7 & 29.8 & 26.5 & 42.0 & 23.2 & 32.5 \\
\hline 9 & Böhmen & 110.7 & 31.6 & 26.5 & 47.9 & 36.9 & 31.5 & 46.4 & 27.6 & 36.4 \\
\hline 10 & Mähren & 100.1 & 26.8 & 23.1 & 43.7 & 36.0 & 38.5 & 54.4 & 33.9 & 43.5 \\
\hline 11 & Schlesien & 113.3 & 26.1 & 23.9 & 37.3 & 33.5 & 31.9 & 54.5 & 35.0 & 46.5 \\
\hline 12 & Krakau sammt Gebiet & 72.2 & 18.6 & 13.8 & 32.7 & 21.9 & 34.3 & 49.9 & 39.3 & 57.3 \\
\hline 13 & Galizien & 85.0 & 26.5 & 20.3 & 38.3 & 29.2 & 46.1 & 46.7 & 52.2 & 73.9 \\
\hline 14 & Bukovina & 72.1 & 21.6 & 17.8 & 34.4 & 32.1 & 48.9 & 53.2 & 65.8 & 65.6 \\
\hline 16 & Lombardie & 154.8 & 21.1 & 17.0 & 33.2 & 26.9 & 30.6 & 48.8 & 28.1 & 36.0 \\
\hline 17 & Venedig & 215.0 & 19.6 & 12.7 & 21.6 & 18.4 & 23.8 & 42.7 & 26.7 & 37.9 \\
\hline 18 & Ungern & 123.7 & 29.4 & 21.9 & 38.1 & 28.3 & 39.2 & 50.4 & 51.9 & 69.2 \\
\hline 19 & Serbische Wojwodschaft und Temeser Banat & 112.5 & 20.5 & 15.0 & 30.2 & 22.4 & 34.3 & 43.8 & 44.1 & 56.9 \\
\hline 21 & Siebenbürgen & 80.9 & 20.0 & 13.2 & 25.4 & 18.0 & 28.3 & 28.8 & 31.6 & 44.1 \\
\hline 22 & $\begin{array}{l}\text { Militärgränze } \\
\text { Total Empire }\left(^{*}\right)\end{array}$ & $\begin{array}{r}107.6 \\
118.4\end{array}$ & $\begin{array}{l}24.2 \\
26.3\end{array}$ & 20.6 & $\begin{array}{r}41.4 \\
37.4\end{array}$ & $\begin{array}{r}24.1 \\
28.4\end{array}$ & 46.0 & 50.1 & $\begin{array}{c}66.8 \\
40.3\end{array}$ & $\begin{array}{c}85.0 \\
-\overline{54.3}\end{array}$ \\
\hline
\end{tabular}

$\left(^{*}\right)$ Oesterreich unter der Enns, Dalmatien, and Kroatien und Slavonien not included. 
Table 8: Life tables for the first 36 months of life. Cohort born in 1851 in the Länder of the Austrian Empire. Index numbers of death probability ${ }_{\mathrm{n}} \mathbf{q}_{\mathrm{x}}$ (Austrian Empire $=100$ )

\begin{tabular}{|c|c|c|c|c|c|c|c|c|c|c|}
\hline \multirow[b]{3}{*}{$\mathbf{n}$} & \multirow[b]{3}{*}{ KronLänder } & \multicolumn{9}{|c|}{ Age (months) } \\
\hline & & \multicolumn{3}{|c|}{ Monthly probability } & \multicolumn{3}{|c|}{ Quarterly probability } & \multicolumn{2}{|c|}{$\begin{array}{c}\text { Biyearly } \\
\text { probability }\end{array}$} & \multirow{2}{*}{$\begin{array}{c}\begin{array}{c}\text { Annual } \\
\text { probability }\end{array} \\
{ }_{12} q_{24} \\
(24-35)\end{array}$} \\
\hline & & $\begin{array}{l}q_{0} \\
(0)\end{array}$ & $\begin{array}{l}q_{1} \\
(1)\end{array}$ & $\begin{array}{l}q_{2} \\
(2)\end{array}$ & $\begin{array}{c}{ }_{3} q_{3} \\
(3-5)\end{array}$ & $\begin{array}{c}{ }_{3} q_{6} \\
(6-8)\end{array}$ & $\begin{array}{c}{ }_{3} q_{9} \\
(9-11)\end{array}$ & $\begin{array}{c}{ }_{6} q_{12} \\
(12-17)\end{array}$ & $\begin{array}{c}{ }_{6} q_{18} \\
(18-23)\end{array}$ & \\
\hline 1 & Oesterreich unter der Enns & 143.4 & 206.5 & 214.7 & 219.6 & 190.2 & 127.8 & - & - & - \\
\hline 2 & Oesterreich ob der Enns & 106.9 & 133.7 & 158.8 & 150.4 & 113.7 & 72.1 & 77.6 & 51.5 & 71.6 \\
\hline 3 & Salzburg & 119.8 & 127.4 & 144.9 & 151.6 & 144.0 & 82.1 & 83.4 & 39.5 & 35.9 \\
\hline 4 & Steiermark & 94.4 & 121.2 & 129.3 & 117.3 & 100.0 & 69.6 & 82.4 & 48.1 & 57.6 \\
\hline 5 & Kärnthen & 102.2 & 92.9 & 105.2 & 100.4 & 90.0 & 57.8 & 59.2 & 29.5 & 42.7 \\
\hline 6 & Krain & 59.9 & 65.3 & 67.7 & 74.2 & 78.4 & 74.7 & 89.5 & 65.8 & 93.7 \\
\hline 7 & $\begin{array}{l}\text { Görz, Gradisca und Istrien, Triest sammt } \\
\text { Gebiet }\end{array}$ & 89.4 & 81.4 & 83.7 & 74.5 & 102.6 & 102.5 & 120.0 & 93.2 & 95.9 \\
\hline 8 & Tirol und Vorarlberg & 109.8 & 78.7 & 85.0 & 90.2 & 105.0 & 74.2 & 90.2 & 57.7 & 59.9 \\
\hline 9 & Böhmen & 93.5 & 120.2 & 128.9 & 128.1 & 129.9 & 88.2 & 99.8 & 68.4 & 67.1 \\
\hline 10 & Mähren & 84.6 & 102.0 & 112.3 & 116.7 & 126.7 & 107.7 & 116.9 & 84.1 & 80.1 \\
\hline 11 & Schlesien & 95.7 & 99.3 & 116.6 & 99.7 & 118.1 & 89.4 & 117.2 & 86.9 & 85.7 \\
\hline 12 & Krakau sammt Gebiet & 61.0 & 70.6 & 67.4 & 87.4 & 77.1 & 96.0 & 107.2 & 97.5 & 105.4 \\
\hline 13 & Galizien & 71.8 & 100.7 & 98.8 & 102.3 & 102.8 & 129.0 & 100.4 & 129.6 & 136.1 \\
\hline 14 & Bukovina & 60.9 & 82.1 & 86.9 & 92.1 & 113.0 & 136.8 & 114.4 & 163.2 & 120.8 \\
\hline 16 & Lombardie & 130.7 & 80.3 & 82.9 & 88.6 & 94.9 & 85.7 & 105.0 & 69.8 & 66.2 \\
\hline 17 & Venedig & 181.6 & 74.5 & 61.8 & 57.7 & 64.7 & 66.5 & 91.8 & 66.2 & 69.8 \\
\hline 18 & Ungern & 104.5 & 111.6 & 106.5 & 101.8 & 99.6 & 109.7 & 108.4 & 128.7 & 127.5 \\
\hline 19 & Serbische Wojwodschaft und Temeser Banat & 95.1 & 77.9 & 73.0 & 80.6 & 78.8 & 96.0 & 94.1 & 109.4 & 104.8 \\
\hline 21 & Siebenbürgen & 68.3 & 76.0 & 64.3 & 67.8 & 63.3 & 79.3 & 61.9 & 78.4 & 81.2 \\
\hline 22 & Militärgränze & 90.9 & 92.1 & 100.4 & 110.8 & 84.8 & 128.7 & 107.7 & 165.7 & 156.6 \\
\hline & Total Empire $\left({ }^{*}\right)$ & 100.0 & 100.0 & 100.0 & 100.0 & 100.0 & 100.0 & 100.0 & 100.0 & 100.0 \\
\hline & Standard deviation & 29.9 & 34.0 & 37.7 & 36.6 & 29.5 & 23.3 & 17.7 & 38.7 & 32.0 \\
\hline
\end{tabular}

$\left(^{*}\right)$ Oesterreich unter der Enns, Dalmatien, and Kroatien und Slavonien not included. 
Table 9: Life tables for the first 36 months of life. Cohort born in 1851 in the Länder of the Austrian Empire. Survival function $\mathrm{I}_{\mathrm{x}}$

\begin{tabular}{|c|c|c|c|c|c|c|c|c|c|c|c|}
\hline \multirow[b]{2}{*}{$\mathbf{n}$} & \multirow[b]{2}{*}{ KronLänder } & \multicolumn{10}{|c|}{ Exact age (months) } \\
\hline & & 0 & 1 & 2 & 3 & 6 & 9 & 12 & 18 & 24 & 36 \\
\hline 1 & Oesterreich unter der Enns & 100,000 & 83,023 & 78,514 & 75,052 & 68,888 & 65,170 & 62,196 & - & - & - \\
\hline 2 & Oesterreich ob der Enns & 100,000 & 87,345 & 84,273 & 81,525 & 76,940 & 74,459 & 72,540 & 69,922 & 68,471 & 65,809 \\
\hline 3 & Salzburg & 100,000 & 85,811 & 82,935 & 80,475 & 75,915 & 72,813 & 70,677 & 67,935 & 66,855 & 65,548 \\
\hline 4 & Steiermark & 100,000 & 88,824 & 85,992 & 83,709 & 80,034 & 77,762 & 75,829 & 72,924 & 71,511 & 69,275 \\
\hline 5 & Kärnthen & 100,000 & 87,902 & 85,753 & 83,901 & 80,751 & 78,690 & 77,064 & 74,943 & 74,053 & 72,337 \\
\hline 6 & Krain & 100,000 & 92,913 & 91,318 & 90,049 & 87,550 & 85,602 & 83,318 & 79,850 & 77,732 & 73,776 \\
\hline 7 & $\begin{array}{l}\text { Görz, Gradisca und Istrien, Triest } \\
\text { und territorio }\end{array}$ & 100,000 & 89,411 & 87,497 & 85,993 & 83,595 & 81,162 & 78,189 & 73,825 & 71,055 & 67,355 \\
\hline 8 & Tirol und Vorarlberg & 100,000 & 87,003 & 85,201 & 83,715 & 80,891 & 78,482 & 76,402 & 73,196 & 71,494 & 69,170 \\
\hline 9 & Böhmen & 100,000 & 88,926 & 86,114 & 83,836 & 79,818 & 76,876 & 74,453 & 70,998 & 69,042 & 66,527 \\
\hline 10 & Mähren & 100,000 & 89,989 & 87,575 & 85,556 & 81,821 & 78,879 & 75,845 & 71,719 & 69,289 & 66,275 \\
\hline 11 & Schlesien & 100,000 & 88,672 & 86,356 & 84,288 & 81,146 & 78,426 & 75,922 & 71,783 & 69,269 & 66,045 \\
\hline 12 & Krakau sammt Gebiet & 100,000 & 92,776 & 91,054 & 89,794 & 86,859 & 84,958 & 82,044 & 77,954 & 74,893 & 70,605 \\
\hline 13 & Galizien & 100,000 & 91,496 & 89,073 & 87,266 & 83,926 & 81,478 & 77,724 & 74,095 & 70,226 & 65,036 \\
\hline 14 & Bukovina & 100,000 & 92,794 & 90,791 & 89,171 & 86,100 & 83,339 & 79,267 & 75,049 & 70,113 & 65,514 \\
\hline 16 & Lombardie & 100,000 & 84,525 & 82,740 & 81,332 & 78,635 & 76,517 & 74,176 & 70,553 & 68,569 & 66,102 \\
\hline 17 & Venedig & 100,000 & 78,499 & 76,961 & 75,985 & 74,343 & 72,978 & 71,244 & 68,203 & 66,384 & 63,868 \\
\hline 18 & Ungern & 100,000 & 87,625 & 85,052 & 83,192 & 80,024 & 77,763 & 74,715 & 70,948 & 67,268 & 62,610 \\
\hline 19 & $\begin{array}{l}\text { Serbische Wojwodschaft und } \\
\text { Temeser Banat }\end{array}$ & 100,000 & 88,746 & 86,927 & 85,623 & 83,041 & 81,184 & 78,400 & 74,968 & 71,662 & 67,582 \\
\hline 21 & Siebenbürgen & 100,000 & 91,908 & 90,071 & 88,882 & 86,628 & 85,072 & 82,664 & 80,285 & 77,750 & 74,320 \\
\hline 22 & Militärgränze & 100,000 & 89,238 & 87,075 & 85,280 & 81,746 & 79,778 & 76,111 & 72,298 & 67,471 & 61,733 \\
\hline & Total Empire $\left(^{*}\right)$ & 100,000 & 88,160 & 85,842 & 84,079 & 80,934 & 78,638 & 75,829 & 72,301 & 69,388 & 65,620 \\
\hline
\end{tabular}

$\left(^{*}\right)$ Oesterreich unter der Enns, Dalmatien, and Kroatien und Slavonien not included. 
Table 10: Life tables for the first 36 months of life. Cohort born in 1851 in the Länder of the Austrian Empire. Deaths out of 100,000 births ${ }_{n} d_{x}$

\begin{tabular}{|c|c|c|c|c|c|c|c|c|c|c|}
\hline \multirow[b]{2}{*}{$\mathrm{n}$} & \multirow[b]{2}{*}{ KronLänder } & \multicolumn{9}{|c|}{ Age (months) } \\
\hline & & 0 & 1 & 2 & 3-5 & 6-8 & $9-11$ & $12-17$ & $18-23$ & 24-35 \\
\hline 1 & Oesterreich unter der Enns & 16,977 & 4,508 & 3,462 & 6,164 & 3,718 & 2,974 & - & - & - \\
\hline 2 & Oesterreich ob der Enns & 12,655 & 3,072 & 2,747 & 4,586 & 2,481 & 1,919 & 2,618 & 1,451 & 2,662 \\
\hline 3 & Salzburg & 14,189 & 2,875 & 2,460 & 4,560 & 3,101 & 2,137 & 2,741 & 1,081 & 1,306 \\
\hline 4 & Steiermark & 11,176 & 2,832 & 2,283 & 3,675 & 2,272 & 1,933 & 2,905 & 1,413 & 2,236 \\
\hline 5 & Kärnthen & 12,098 & 2,149 & 1,852 & 3,150 & 2,061 & 1,626 & 2,122 & 890 & 1,716 \\
\hline 6 & Krain & 7,087 & 1,595 & 1,269 & 2,499 & 1,948 & 2,284 & 3,467 & 2,118 & 3,956 \\
\hline 7 & $\begin{array}{l}\text { Görz, Gradisca und Istrien, Triest sammt } \\
\text { Gebiet }\end{array}$ & 10,589 & 1,914 & 1,504 & 2,397 & 2,434 & 2,973 & 4,363 & 2,771 & 3,699 \\
\hline 8 & Tirol und Vorarlberg & 12,997 & 1,802 & 1,486 & 2,824 & 2,409 & 2,080 & 3,206 & 1,701 & 2,324 \\
\hline 9 & Böhmen & 11,074 & 2,812 & 2,279 & 4,018 & 2,942 & 2,423 & 3,455 & 1,956 & 2,515 \\
\hline 10 & Mähren & 10,011 & 2,414 & 2,019 & 3,735 & 2,942 & 3,034 & 4,126 & 2,430 & 3,014 \\
\hline 11 & Schlesien & 11,328 & 2,315 & 2,068 & 3,142 & 2,720 & 2,504 & 4,139 & 2,515 & 3,224 \\
\hline 12 & Krakau sammt Gebiet & 7,224 & 1,723 & 1,260 & 2,935 & 1,901 & 2,913 & 4,090 & 3,062 & 4,288 \\
\hline 13 & Galizien & 8,504 & 2,422 & 1,807 & 3,340 & 2,448 & 3,754 & 3,629 & 3,868 & 5,191 \\
\hline 14 & Bukovina & 7,206 & 2,003 & 1,620 & 3,071 & 2,761 & 4,073 & 4,218 & 4,936 & 4,599 \\
\hline 16 & Lombardie & 15,475 & 1,785 & 1,408 & 2,697 & 2,118 & 2,341 & 3,622 & 1,984 & 2,467 \\
\hline 17 & Venedig & 21,501 & 1,539 & 976 & 1,641 & 1,365 & 1,734 & 3,041 & 1,819 & 2,516 \\
\hline 18 & Ungern & 12,375 & 2,573 & 1,860 & 3,168 & 2,261 & 3,048 & 3,767 & 3,680 & 4,658 \\
\hline 19 & $\begin{array}{l}\text { Serbische Wojwodschaft und Temeser } \\
\text { Banat }\end{array}$ & 11,254 & 1,819 & 1,304 & 2,582 & 1,857 & 2,784 & 3,432 & 3,306 & 4,080 \\
\hline 21 & Siebenbürgen & 8,092 & 1,837 & 1,189 & 2,254 & 1,556 & 2,408 & 2,379 & 2,535 & 3,431 \\
\hline 22 & Militärgränze & 10,762 & 2,163 & 1,795 & 3,534 & 1,968 & 3,667 & 3,813 & 4,827 & 5,737 \\
\hline & Total Empire $\left(^{*}\right)$ & 11,840 & 2,319 & 1,763 & 3,145 & 2,296 & 2,809 & 3,527 & 2,913 & 3,768 \\
\hline
\end{tabular}

(*) Oesterreich unter der Enns, Dalmatien, and Kroatien und Slavonien not included. 
Table 11: Life tables for the first 3 years of life. Cohort born in 1851 in the Länder of the Austrian Empire. Annual death probability $\left(1,000 \times q_{x}\right)$

\begin{tabular}{|c|c|c|c|c|c|}
\hline \multirow[b]{2}{*}{$\mathbf{n}$} & \multirow[b]{2}{*}{ KronLänder } & \multicolumn{3}{|c|}{ Annual probability } & \multirow{2}{*}{$\begin{array}{c}\begin{array}{c}3 \text { years } \\
\text { probability }\end{array} \\
{ }_{3} q_{0} \\
\end{array}$} \\
\hline & & $q_{0}$ & $q_{1}$ & $q_{2}$ & \\
\hline 1 & Oesterreich unter der Enns & 378.0 & - & - & - \\
\hline 2 & Oesterreich ob der Enns & 274.6 & 56.1 & 38.9 & 341.9 \\
\hline 3 & Salzburg & 293.2 & 54.1 & 19.5 & 344.5 \\
\hline 4 & Steiermark & 241.7 & 56.9 & 31.3 & 307.3 \\
\hline 5 & Kärnthen & 229.4 & 39.1 & 23.2 & 276.6 \\
\hline 6 & Krain & 166.8 & 67.0 & 50.9 & 262.2 \\
\hline 7 & Görz, Gradisca und Istrien, Triest sammt Gebiet & 218.1 & 91.2 & 52.1 & 326.4 \\
\hline 8 & Tirol und Vorarlberg & 236.0 & 64.2 & 32.5 & 308.3 \\
\hline 9 & Böhmen & 255.5 & 72.7 & 36.4 & 334.7 \\
\hline 10 & Mähren & 241.6 & 86.4 & 43.5 & 337.3 \\
\hline 11 & Schlesien & 240.8 & 87.6 & 46.5 & 339.6 \\
\hline 12 & Krakau sammt Gebiet & 179.6 & 87.2 & 57.3 & 294.0 \\
\hline 13 & Galizien & 222.8 & 96.5 & 73.9 & 349.6 \\
\hline 14 & Bukovina & 207.3 & 115.5 & 65.6 & 344.9 \\
\hline 16 & Lombardie & 258.2 & 75.6 & 36.0 & 339.0 \\
\hline 17 & Venedig & 287.6 & 68.2 & 37.9 & 361.3 \\
\hline 18 & Ungern & 252.9 & 99.7 & 69.2 & 373.9 \\
\hline 19 & Serbische Wojwodschaft und Temeser Banat & 216.0 & 85.9 & 56.9 & 324.2 \\
\hline 21 & Siebenbürgen & 173.4 & 59.4 & 44.1 & 256.8 \\
\hline 22 & Militärgränze & 238.9 & 113.5 & 85.0 & 382.7 \\
\hline & Total Empire $\left(^{*}\right)$ & 241.7 & 84.9 & 54.3 & 343.8 \\
\hline
\end{tabular}

$\left(^{*}\right)$ Oesterreich unter der Enns, Dalmatien, and Kroatien und Slavonien not included. 
Table 12: Confidence intervals for the death probabilities during the first 36 months of life. Länder with the lowest number of births in 1851 (see first column of table 3)

\begin{tabular}{|c|c|c|c|c|c|c|c|c|c|c|}
\hline \multirow{2}{*}{\multicolumn{2}{|c|}{ Länder and births in 1851}} & \multicolumn{9}{|c|}{ Age (months) } \\
\hline & & \multirow{2}{*}{$\begin{array}{c}0 \\
141.9\end{array}$} & \multirow{2}{*}{$\frac{1}{33.5}$} & \multirow{2}{*}{$\frac{2}{29.7}$} & \multirow{2}{*}{$\begin{array}{c}3-5 \\
56.7\end{array}$} & \multirow{2}{*}{$\begin{array}{c}6-8 \\
40.9\end{array}$} & \multirow{2}{*}{$\begin{array}{r}9-11 \\
29.3\end{array}$} & \multirow{2}{*}{$\frac{12-17}{38.8}$} & \multirow{2}{*}{$\frac{18-23}{15.9}$} & \multirow{2}{*}{$\begin{array}{r}24-35 \\
19.5\end{array}$} \\
\hline Salzburg & $q_{x}$ & & & & & & & & & \\
\hline$(4,095)$ & Intervals & \pm 11.5 & \pm 6.1 & \pm 5.8 & \pm 8.1 & \pm 7.1 & \pm 6.1 & \pm 7.2 & \pm 4.7 & \pm 5.2 \\
\hline Krakau & $\mathrm{q}_{\mathrm{x}}$ & 72.2 & 18.6 & 13.8 & 32.7 & 21.9 & 34.3 & 49.9 & 39.3 & 57.3 \\
\hline$(6,320)$ & Intervals & \pm 6.6 & \pm 3.5 & \pm 3.0 & \pm 4.7 & \pm 3.9 & \pm 5.0 & \pm 6.1 & \pm 5.5 & \pm 6.8 \\
\hline Karnthen & $\mathrm{q}_{\mathrm{x}}$ & 121 & 24.4 & 21.6 & 37.5 & 25.5 & 20.7 & 27.5 & 11.9 & 23.2 \\
\hline$(9,297)$ & Intervals & \pm 7.1 & \pm 3.4 & \pm 3.2 & \pm 4.3 & \pm 3.6 & \pm 3.3 & \pm 3.8 & \pm 2.6 & \pm 3.6 \\
\hline
\end{tabular}

A first look at the differences between regions suggests that some information may have been under-registered. In five of the regions, the probability of dying during the first month is lower than $100 \%$. In the regions of Krain and Krakau, this relatively low level corresponds to low mortality during the two months which follow, whereas in Bukovina, Galizien, and Siebenbürgen, this does not occur (Table 7). Consequently, in these three Länder neonatal mortality may have been under-registered.

We now turn to the results in Table 7, where the probabilities ${ }_{n} q_{x}$, are expressed in months, by age intervals of different size $n$. After three months of life, in some Länder the probability of death at several ages is higher than the analogous probability at the preceding age. For example, ${ }_{3} \mathrm{q}_{6}$ is greater than ${ }_{3} \mathrm{q}_{3}$ only in the Länder Görz, Gradisca und Istrien, and Triest sammt Gebiet; but ${ }_{3} \mathrm{q}_{9}$ is higher than ${ }_{3} \mathrm{q}_{6}$ in many central-eastern Länder (Table 13). Similarly, ${ }_{6} \mathrm{q}_{12}$ is higher than ${ }_{6} \mathrm{q}_{6}$ in only one Land, (Venedig), but ${ }_{6} \mathrm{q}_{18}$ is higher than ${ }_{6} \mathrm{q}_{12}$ in six Länder (Galizien, Bukovina, Ungern, Serbische Wojwodschaft und Temeser Banat, Siebenbürgen, and Militärgränze). Although such situations are not impossible, they are rather rare. For example, among the English population between 1580 and 1837 (Wrigley et al. 1997:226), in 11 periods of about 25 years each, the ratio ${ }_{3} \mathrm{q}_{6} /{ }_{3} \mathrm{q}_{3}$ is (only slightly) greater than one only once, and the ratio ${ }_{3} \mathrm{q}_{9} /{ }_{3} \mathrm{q}_{6}$, only twice. These results strongly suggest that great caution should be used when considering some of our results, in particular those relative to the probability that a survivor at nine months will die by 12 months of life, which, in fact, often appears to be higher than the same probability of the preceding trimester. This could be a consequence of possible attractions to terminal numbers, as many of the Länder characterised by this situation are precisely those in which an unusual attraction to the number 9 is seen in the annual life table (Table 6 and Figure 4). 
A strong suspicion that probabilities of death at 9-12 months had been overestimated in several Länder motivated us to join this age class with the two contiguous classes, and hence to jointly calculate the probabilities of death at 6-18 months (Table 14). The greater regularity of these results (only one Land with a higher probability than that of the preceding age class remains) leads us to conclude that the interval of 9-12 months attracts, in part, that of 6-9 months, and, to a lesser extent, that of 12-18 months. However, a somewhat suspect situation still remains - in the Länder with anomalous attractions to numbers - due to the probability of death at ages 18-24 months, which in some cases was found to be higher than that of the preceding semester. The entity of possible error is, however, much smaller than in the preceding case.

Taking all of these observations into consideration, in order to succinctly compare mortality during the first three years of life in the Länder, while simultaneously avoiding problems linked to age-heaping, we use four intervals (Table 14):

- $\quad$ the first month of life $\left(\mathrm{q}_{0}\right)$;

- the following five months $\left({ }_{5} \mathrm{q}_{1}\right)$, given that the territorial series of probabilities $\mathrm{q}_{1}, \mathrm{q}_{2},{ }_{3} \mathrm{q}_{3}$ are highly correlated;

- the 12 months which run from the $7^{\text {th }}$ to the $18^{\text {th }}$ months of life $\left({ }_{12} \mathrm{q}_{6}\right)$;

- the 18 months which run from the $19^{\text {th }}$ to the $36^{\text {th }}$ months of life $\left({ }_{18} q_{18}\right)$.

Figures 7 through 11 show the geography of Länder with elevated, intermediate, and low levels of mortality for the four classes defined above, and for the entire class up to three years of age, highlighting an often evident territorial contiguity of regions with similar levels. 
Table 13: Death probability in the first 36 months of life. Ratio between probabilities (*) for selected periods of life. Cohort born in 1851 in the Länder of the Austrian Empire

\begin{tabular}{|c|c|c|c|c|c|c|}
\hline & \multirow[b]{2}{*}{ Länder } & \multicolumn{2}{|c|}{$\begin{array}{l}\text { Quarterly } \\
\text { probability }\end{array}$} & \multicolumn{2}{|c|}{$\begin{array}{l}\text { Biyearly } \\
\text { probability }\end{array}$} & \multirow{2}{*}{$\begin{array}{c}\begin{array}{c}\text { Annual } \\
\text { probability }\end{array} \\
{ }_{12} q_{24} /{ }_{12} q_{12}\end{array}$} \\
\hline & & ${ }_{3} q_{6} /{ }_{3} q_{3}$ & ${ }_{3} q_{9} /{ }_{3} q_{6}$ & ${ }_{6} q_{12} /{ }_{6} q_{6}$ & ${ }_{6} q_{18} /{ }_{6} q_{12}$ & \\
\hline 1 & Oesterreich unter der Enns & 0.66 & 0.84 & - & - & - \\
\hline 2 & Oesterreich ob der Enns & 0.57 & 0.80 & 0.63 & 0.58 & 0.69 \\
\hline 3 & Salzburg & 0.72 & 0.72 & 0.56 & 0.41 & 0.36 \\
\hline 4 & Steiermark & 0.65 & 0.88 & 0.73 & 0.51 & 0.55 \\
\hline 5 & Kärnthen & 0.68 & 0.81 & 0.60 & 0.43 & 0.59 \\
\hline 6 & Krain & 0.80 & 1.20 & 0.86 & 0.64 & 0.76 \\
\hline 7 & $\begin{array}{l}\text { Görz, Gradisca und Istrien, Triest sammt } \\
\text { Gebiet }\end{array}$ & 1.04 & 1.26 & 0.86 & 0.67 & 0.57 \\
\hline 8 & Tirol und Vorarlberg & 0.88 & 0.89 & 0.76 & 0.55 & 0.51 \\
\hline 9 & Böhmen & 0.77 & 0.85 & 0.69 & 0.59 & 0.50 \\
\hline 10 & Mähren & 0.82 & 1.07 & 0.74 & 0.62 & 0.50 \\
\hline 11 & Schlesien & 0.90 & 0.95 & 0.85 & 0.64 & 0.53 \\
\hline 12 & Krakau sammt Gebiet & 0.67 & 1.57 & 0.90 & 0.79 & 0.66 \\
\hline 13 & Galizien & 0.76 & 1.58 & 0.63 & 1.12 & 0.77 \\
\hline 14 & Bukovina & 0.93 & 1.52 & 0.67 & 1.24 & 0.57 \\
\hline 16 & Lombardie & 0.81 & 1.14 & 0.86 & 0.58 & 0.48 \\
\hline 17 & Venedig & 0.85 & 1.29 & 1.02 & 0.63 & 0.56 \\
\hline 18 & Ungern & 0.74 & 1.39 & 0.76 & 1.03 & 0.69 \\
\hline 19 & $\begin{array}{l}\text { Serbische Wojwodschaft und Temeser } \\
\text { Banat }\end{array}$ & 0.74 & 1.53 & 0.78 & 1.01 & 0.66 \\
\hline 21 & Siebenbürgen & 0.71 & 1.57 & 0.63 & 1.10 & 0.74 \\
\hline 22 & Militärgränze & 0.58 & 1.91 & 0.73 & 1.33 & 0.75 \\
\hline & Total Empire $\left({ }^{\star \star}\right)$ & 0.76 & 1.26 & $0.74^{-}$ & $0.87^{-}$ & 0.64 \\
\hline & Males & 0.74 & 1.21 & 0.72 & 0.86 & 0.64 \\
\hline & Females & 0.78 & 1.32 & 0.76 & 0.87 & 0.64 \\
\hline & Total Empire $\left.{ }^{* *}\right)$ & 0.76 & 1.26 & $0.74^{-}$ & $0.87^{-}$ & 0.64 \\
\hline
\end{tabular}

$\left({ }^{*}\right)$ The probability ${ }_{6} q_{6}$ is obtained by: ${ }_{3} q_{6}+\left(1-{ }_{3} q_{6}\right)_{3} q_{9}$; the probability ${ }_{12} q_{12}$ is obtained by: ${ }_{6} q_{12}+\left(1-{ }_{6} q_{12}\right){ }_{6} q_{18}$. $\left.{ }^{* *}\right)$ Dalmatien and Kroatien und Slavonien not included. 
Table 14: Life tables for the first 36 months of life. Cohort born in 1851 in the Länder of the Austrian Empire. Death probability ${ }_{n} q_{x}$ for selected periods of life

\begin{tabular}{|c|c|c|c|c|c|c|c|c|c|c|c|}
\hline \multirow[b]{3}{*}{$\mathbf{n}$} & \multirow[b]{3}{*}{ Länder } & \multicolumn{5}{|c|}{ Level $(x$ 1,000) } & \multicolumn{5}{|c|}{ Rank } \\
\hline & & $q_{0}$ & ${ }_{5} q_{1}$ & ${ }_{12} q_{6}$ & ${ }_{18} q_{18}$ & ${ }_{36} q_{0}$ & $q_{0}$ & ${ }_{5} q_{1}$ & ${ }_{12} q_{6}$ & ${ }_{18} q_{18}$ & ${ }_{36} q_{0}$ \\
\hline & & $(0)$ & $(1-5)$ & $(6-17)$ & $(18-35)$ & $(0-35)$ & (0) & $(1-5)$ & $(6-17)$ & $(18-35)$ & $(0-35)$ \\
\hline 1 & Oesterreich unter der Enns & 170 & 170 & --- & -- & -- & 19 & 20 & -- & -- & --- \\
\hline 2 & Oesterreich ob der Enns & 127 & 119 & 91 & 59 & 342 & 15 & 18 & 6 & 5 & 13 \\
\hline 3 & Salzburg & 142 & 115 & 105 & 35 & 345 & 17 & 19 & 11 & 2 & 14 \\
\hline 4 & Steiermark & 112 & 99 & 89 & 50 & 307 & 10 & 16 & 5 & 3 & 5 \\
\hline 5 & Kärnthen & 121 & 81 & 72 & 35 & 277 & 13 & 10 & 1 & 1 & 3 \\
\hline 6 & Krain & 71 & 58 & 88 & 76 & 262 & 1 & 3 & 4 & 11 & 2 \\
\hline 7 & $\begin{array}{l}\text { Görz, Gradisca und Istrien, Triest } \\
\text { sammt Gebiet }\end{array}$ & 106 & 65 & 117 & 88 & 326 & 7 & 6 & 16 & 13 & 8 \\
\hline 8 & Tirol und Vorarlberg & 130 & 70 & 95 & 55 & 308 & 16 & 8 & 7 & 4 & 6 \\
\hline 9 & Böhmen & 111 & 102 & 111 & 63 & 335 & 9 & 17 & 12 & 6 & 9 \\
\hline 10 & Mähren & 100 & 91 & 124 & 76 & 337 & 6 & 15 & 18 & 10 & 10 \\
\hline 11 & Schlesien & 113 & 85 & 115 & 80 & 340 & 12 & 13 & 14 & 12 & 12 \\
\hline 12 & Krakau sammt Gebiet & 72 & 64 & 103 & 94 & 294 & 3 & 4 & 9 & 14 & 4 \\
\hline 13 & Galizien & 85 & 83 & 117 & 122 & 350 & 5 & 11 & 17 & 17 & 16 \\
\hline 14 & Bukovina & 72 & 72 & 128 & 127 & 345 & 2 & 9 & 19 & 18 & 15 \\
\hline 16 & Lombardie & 155 & 70 & 103 & 63 & 339 & 18 & 7 & 10 & 7 & 11 \\
\hline 17 & Venedig & 215 & 53 & 83 & 64 & 361 & 20 & 1 & 3 & 8 & 17 \\
\hline 18 & Ungern & 124 & 87 & 113 & 118 & 374 & 14 & 14 & 13 & 16 & 18 \\
\hline 19 & $\begin{array}{l}\text { Serbische Wojwodschaft und Temeser } \\
\text { Banat }\end{array}$ & 113 & 64 & 97 & 98 & 324 & 11 & 5 & 8 & 15 & 7 \\
\hline 21 & Siebenbürgen & 81 & 57 & 73 & 74 & 257 & 4 & 2 & 2 & 9 & 1 \\
\hline 22 & Militärgränze & 108 & 84 & 116 & 146 & 383 & 8 & 12 & 15 & 19 & 19 \\
\hline - - & Total Empire $\left(^{*}\right)$ & 118 & 82 & 107 & 92 & 344 & - & - & - & 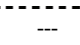 & - \\
\hline
\end{tabular}

$\left(^{*}\right)$ Oesterreich unter der Enns, Dalmatien, and Kroatien und Slavonien not included. 
Figure 7: Life tables for the first 36 months of life. Cohort born in 1851 in the Länder of the Austrian Empire. Death probability for the first month of life $\left(q_{0}\right)$

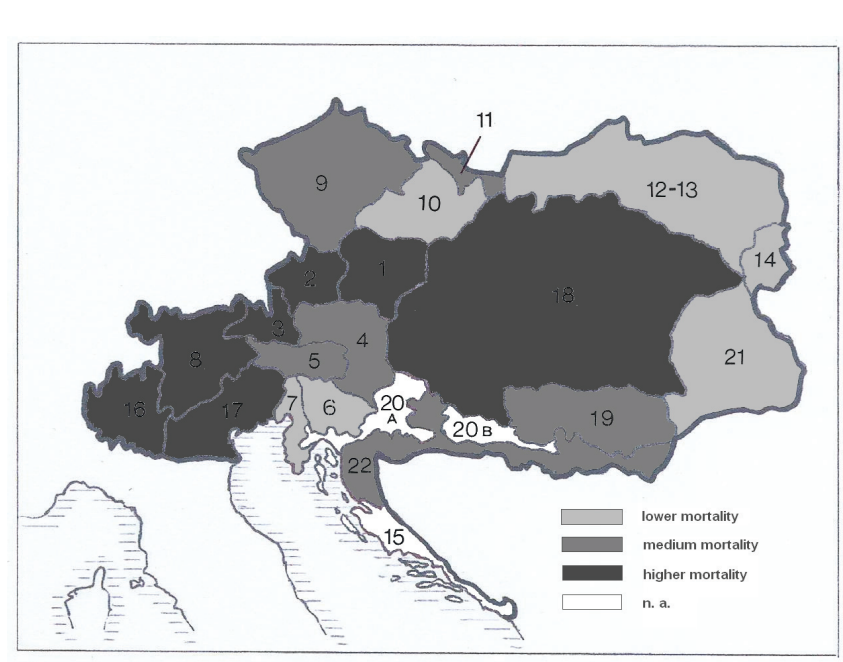

\begin{tabular}{|c|l|}
\hline $\mathbf{n}$ & Länder \\
\hline 1 & Oesterreich unter der Enns \\
2 & Oesterreich ob der Enns \\
3 & Salzburg \\
4 & Steiermark \\
5 & Kärnthen \\
6 & Krain \\
7 & Görz, Gradisca, Istrien, Triest \\
& sammt Gebiet (Kustenland) \\
8 & Tirol und Vorarlberg \\
9 & Böhmen \\
10 & Mähren \\
11 & Schlesien \\
$13-12$ & Galizien und Krakau \\
14 & Bukowina \\
15 & Dalmatien \\
16 & Lombardie \\
17 & Venedig \\
18 & Ungern \\
19 & Serbische Wojwodschaft \\
& und Temeser Banat \\
20 & Kroatien (A) und Slavonien (B) \\
21 & Siebenbürgen \\
22 & Militärgränze \\
\hline
\end{tabular}


Figure 8: Life tables for the first 36 months of life. Cohort born in 1851 in the Länder of the Austrian Empire. Death probability from the 2nd to 6th months for those surviving to the 1st month $\left({ }_{5} q_{1}\right)$

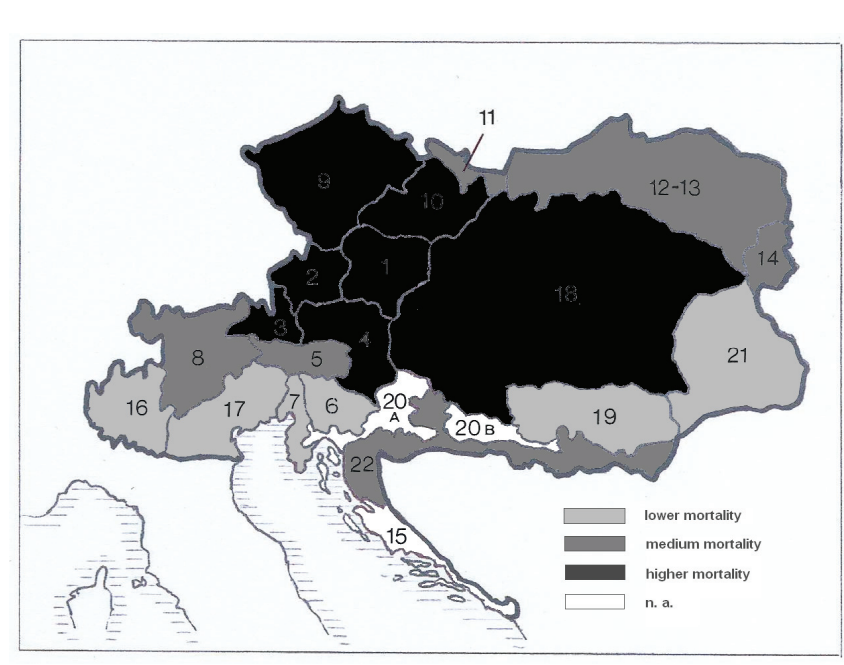

\begin{tabular}{|c|l|}
\hline $\mathbf{n}$ & Länder \\
\hline 1 & Oesterreich unter der Enns \\
2 & Oesterreich ob der Enns \\
3 & Salzburg \\
4 & Steiermark \\
5 & Kärnthen \\
6 & Krain \\
7 & Görz, Gradisca, Istrien, Triest \\
& sammt Gebiet (Kustenland) \\
8 & Tirol und Vorarlberg \\
9 & Böhmen \\
10 & Mähren \\
11 & Schlesien \\
$13-12$ & Galizien und Krakau (*) \\
14 & Bukowina \\
15 & Dalmatien \\
16 & Lombardie \\
17 & Venedig \\
18 & Ungern \\
19 & Serbische Wojwodschaft \\
20 & und Temeser Banat \\
21 & Kroatien (A) und Slavonien (B) \\
22 & Siebenbürgen \\
\hline
\end{tabular}

$\left.{ }^{*}\right)$ Galizien has medium mortality, while Krakau sammt Gebiet has lower mortality. 
Figure 9: Life tables for the first 36 months of life. Cohort born in 1851 in the Länder of the Austrian Empire. Death probability from the 7th to 18th months for those surviving to the 6th month $\left({ }_{12} q_{6}\right)$

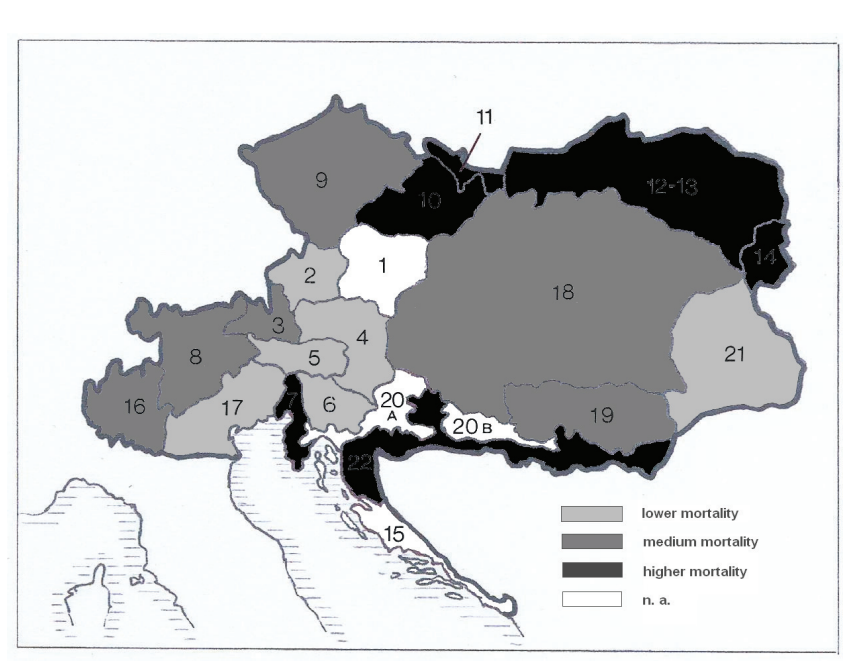

\begin{tabular}{|c|l|}
\hline $\mathbf{n}$ & Länder \\
\hline 1 & Oesterreich unter der Enns \\
3 & Oesterreich ob der Enns \\
4 & Salzburg \\
5 & Steiermark \\
6 & Kärnthen \\
7 & Krain \\
& Görz, Gradisca, Istrien, Triest \\
8 & sammt Gebiet (Kustenland) \\
9 & Tirol und Vorarlberg \\
10 & Mähren \\
11 & Schlesien \\
$13-12$ & Galizien und Krakau ( $\left.{ }^{*}\right)$ \\
14 & Bukowina \\
15 & Dalmatien \\
16 & Lombardie \\
17 & Venedig \\
18 & Ungern \\
19 & Serbische Wojwodschaft \\
20 & und Temeser Banat \\
21 & Kroatien (A) und Slavonien (B) \\
22 & Militärgränze \\
\hline
\end{tabular}

$\left(^{*}\right)$ Galizien has medium mortality, while Krakau sammt Gebiet has lower mortality. 
Figure 10: Life tables for the first 36 months of life. Cohort born in 1851 in the Länder of the Austrian Empire. Death probability from the 19th to 36th months for those surviving to the 18th month $\left({ }_{18} \mathrm{q}_{18}\right)$

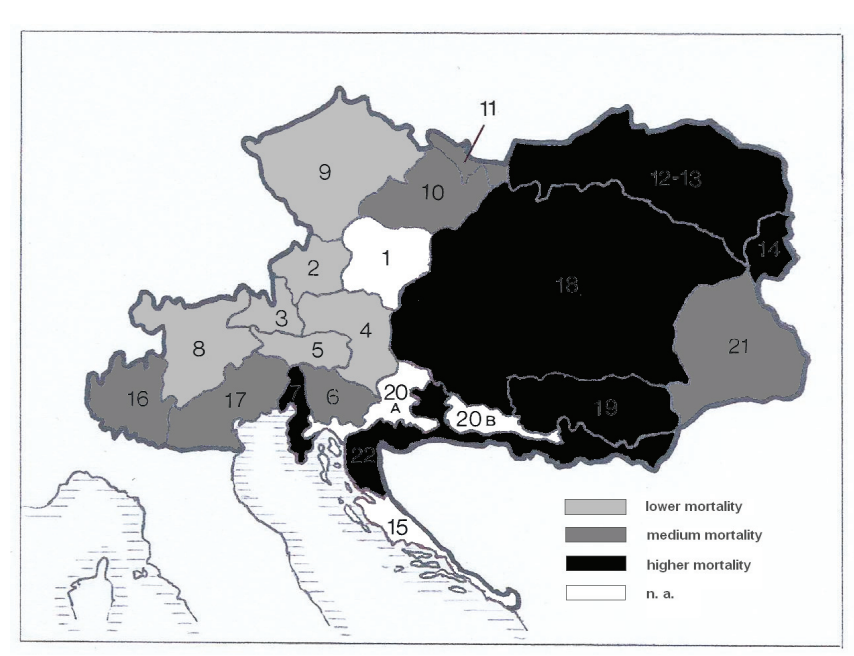

\begin{tabular}{|c|l|}
\hline $\mathbf{n}$ & Länder \\
\hline 1 & Oesterreich unter der Enns \\
2 & Oesterreich ob der Enns \\
3 & Salzburg \\
4 & Steiermark \\
5 & Kärnthen \\
7 & Krain \\
& Görz, Gradisca, Istrien, Triest \\
8 & sammt Gebiet (Kustenland) \\
9 & Tirol und Vorarlberg \\
10 & Böhmen \\
11 & Sähren \\
$13-12$ & Salizien und Krakau \\
14 & Bukowina \\
15 & Dalmatien \\
16 & Lombardie \\
17 & Venedig \\
18 & Ungern \\
19 & Serbische Wojwodschaft \\
20 & und Temeser Banat \\
21 & Kroatien (A) und Slavonien (B) \\
22 & Miebenbürgen \\
\hline
\end{tabular}


Figure 11: Life tables for the first 36 months of life. Cohort born in 1851 in the Länder of the Austrian Empire. Death probability for the first 3 years of life $\left({ }_{36} q_{0}\right)$

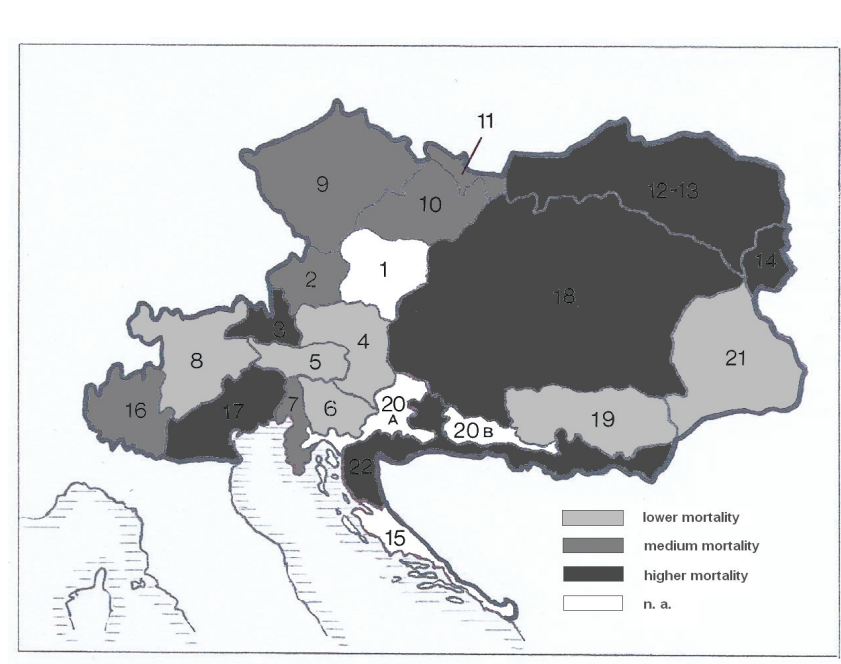

\begin{tabular}{|c|l|}
\hline $\mathbf{n}$ & Länder \\
\hline 1 & Oesterreich unter der Enns \\
2 & Oesterreich ob der Enns \\
3 & Salzburg \\
4 & Steiermark \\
5 & Kärnthen \\
6 & Krain \\
7 & Görz, Gradisca, Istrien, Triest \\
& sammt Gebiet (Kustenland) \\
8 & Tirol und Vorarlberg \\
9 & Böhmen \\
10 & Mähren \\
11 & Schlesien \\
$13-12$ & Galizien und Krakau ${ }^{*}$ ) \\
14 & Bukowina \\
15 & Dalmatien \\
16 & Lombardie \\
17 & Venedig \\
18 & Ungern \\
19 & Serbische Wojwodschaft \\
& und Temeser Banat \\
20 & Kroatien (A) und Slavonien (B) \\
21 & Siebenbürgen \\
22 & Militärgränze \\
\hline
\end{tabular}

$\left({ }^{*}\right)$ Galizien has medium mortality, while Krakau sammt Gebiet has lower mortality. 


\section{A brief discussion of territorial differences}

The main aim of this article is methodological: to test the quality of detailed data published in the mid- $19^{\text {th }}$ century Tafeln on infant mortality in the Austrian Empire Länder. In the previous section, we suggested that the quality of the data is relatively good, with the exception of information on stillbirths and that on age at death in some Länder. In these final sections, we conclude by briefly discussing several substantive topics, emphasising geographical aspects.

A complete comparison of the Länder must take into account the larger demographic history of each Land (or at least infant mortality). The Tafeln may be very useful for describing the long-term processes of infant mortality, as they cover the long time-span of 1829-1871. These statistical tables also allow scholars to cross infant mortality with several specific characteristics of the Länder, such as education, urbanization, religion, economic situation, etc. The published life tables presented here thus represent only a snapshot of a potentially much broader picture.

In addition, data of this type (when sufficient quality exists) allow for regional comparisons of an Empire that was home to 35 million people - an uncommon situation during the ancien régime. Our results provide support for Livi Bacci's argument cited at the beginning of this article: territorial variability is notable, and standard deviations are large and similar for each series of death probabilities. Moreover, in some cases, bordering Länder are characterised by opposite levels (see for example, the differences among the Länder in actual Austria (the first five rows of Table 8), as already emphasised by other authors (Prioux 1993; Kytir, Köck, and Münz 1995; Viazzo 1997).

Overall mortality in the first three years of life is quite variable, as has already been observed (Figures 11 and 12). High levels, or those of 350\%o and beyond, appear in the eastern (Galizien, Bukovina, Ungern), southern (Militärgränze), and western (Venedig, Salzburg) regions. Nonetheless, the distribution by age at death across the first three years of life in the different regions is quite diverse (Figures 7-10). Mortality is rather high in the first month throughout a vast western and central area, which reaches as far as Ungern. Between the second and the sixth months, the probability of death is instead higher in the central regions. Indeed, a closer look at Figure 8 shows great continuity, but also a certain gradient towards the more peripheral areas, particularly the more southern regions (with the exception of Militärgränze). For the age interval between the $7^{\text {th }}$ and the $18^{\text {th }}$ months (Figure 9),we see almost the inverse: low mortality in the central regions and high mortality in the northern (Mähren, Schlesien, Galizien, Bukovina) and southern (Militärgränze, Istrien) peripheral regions. Finally, at over 18 months (Figure 10), mortality is higher in the eastern and southern Länder, and lower in the central and northern regions. 
Figure 12: Life tables for the first 36 months of life. Cohort born in 1851 in the Länder of the Austrian Empire. Variability of the survival function $I_{x}$

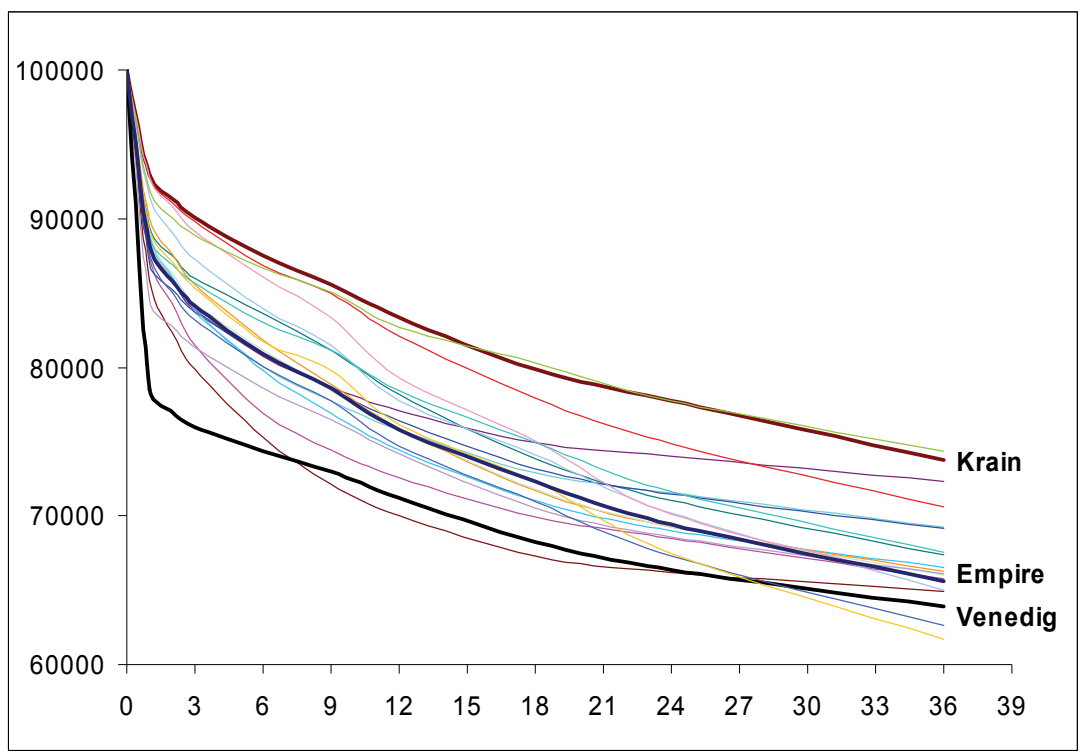

\section{Was there discrimination against female children?}

Differences by sex are not widely apparent for the Empire as a whole (Tables 15 and 16 and Figure 13). Males are penalized at every age, although this difference declines after the ninth month of life. On the other hand, the Empire's mean values hide deep regional differences. Consider, for example, four "extreme" situations. In Steiermark, the generally low level of infant mortality is mainly due to the high survival rates of females. Similarly, in Salzburg, low mortality after the ninth month is caused by the high survival rates of females. In Bukovina, on the other hand, infant mortality is very high after the ninth month of life due to very high female mortality. Finally, in Venedig, very high neonatal mortality is similarly due to the lack of female under-mortality. 
Table 15: Life tables for the first 36 months of life. Cohort born in 1851 in the Länder of the Austrian Empire. Death probability $\left(1,000 \mathbf{X}_{\mathrm{n}} \mathbf{q}_{\mathrm{x}}\right)$ for males and females

\begin{tabular}{|c|c|c|c|c|c|c|c|c|c|}
\hline \multirow[b]{3}{*}{ Sex } & \multicolumn{9}{|c|}{ Age (months) } \\
\hline & \multicolumn{3}{|c|}{ Monthly probability } & \multicolumn{3}{|c|}{$\begin{array}{l}\text { Quarterly } \\
\text { probability }\end{array}$} & \multicolumn{2}{|c|}{$\begin{array}{c}\text { Biyearly } \\
\text { probability }\end{array}$} & \multirow{2}{*}{$\begin{array}{c}\begin{array}{c}\text { Annual } \\
\text { probability }\end{array} \\
{ }_{12} q_{24} \\
(24-35)\end{array}$} \\
\hline & $\begin{array}{l}Q_{0} \\
(0)\end{array}$ & $\begin{array}{l}q_{1} \\
(1)\end{array}$ & $\begin{array}{l}q_{2} \\
(2)\end{array}$ & $\begin{array}{c}{ }_{3} q_{3} \\
(3-5)\end{array}$ & $\begin{array}{c}{ }_{3} q_{6} \\
(6-8)\end{array}$ & $\begin{array}{c}{ }_{3} q_{9} \\
(9-11)\end{array}$ & $\begin{array}{c}{ }_{6} q_{12} \\
(12-17)\end{array}$ & $\begin{array}{c}{ }_{6} q_{18} \\
(18-23)\end{array}$ & \\
\hline Males & 129.8 & 28.3 & 22.2 & 40.8 & 30.3 & 36.7 & 47.5 & 40.8 & 55.3 \\
\hline Females & 106.3 & 24.2 & 18.8 & 33.9 & 26.4 & 34.8 & 45.6 & 39.8 & 53.3 \\
\hline $\begin{array}{l}\text { Total Empire }\left(^{*}\right) \\
100 \times \text { Ratio }\end{array}$ & 118.4 & 26.3 & 20.5 & 37.4 & 28.4 & 35.7 & 46.5 & 40.3 & 54.3 \\
\hline Males/Females & 122.1 & 116.9 & 118.0 & 120.5 & 114.8 & 105.4 & 104.2 & 102.6 & 103.9 \\
\hline
\end{tabular}

$\left({ }^{*}\right)$ Oesterreich unter der Enns, Dalmatien, and Kroatien und Slavonien not included.

Figure 13: Life tables for the first 36 months of life. Cohort born in 1851 in the Länder of the Austrian Empire. Survival function $\mathrm{I}_{\mathrm{x}}$ for males and females

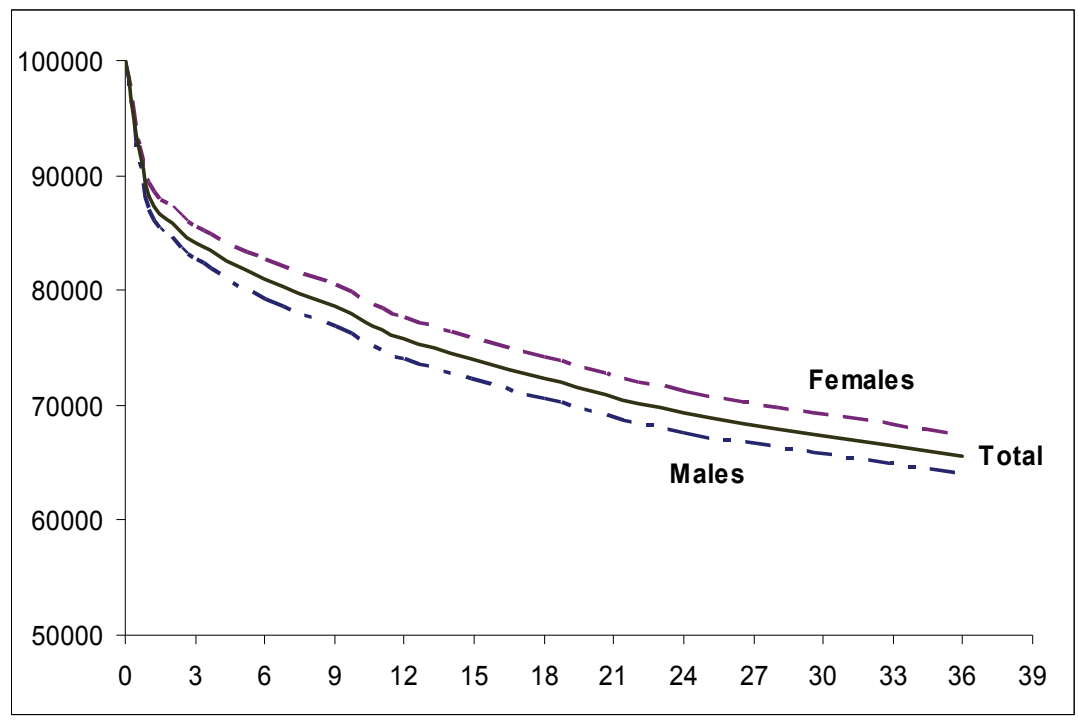


Table 16: Life tables for the first 36 months of life. Cohort born in 1851 in the Länder of the Austrian Empire. 100 x Ratio Males/Females of death probability ${ }_{n} q_{x}$

\begin{tabular}{|c|c|c|c|c|c|c|c|c|c|c|}
\hline \multirow[b]{3}{*}{ n } & \multirow[b]{3}{*}{ KronLänder } & \multicolumn{9}{|c|}{ Age (months) } \\
\hline & & \multicolumn{3}{|c|}{ Monthly probability } & \multicolumn{3}{|c|}{ Quarterly probability } & \multicolumn{2}{|c|}{$\begin{array}{c}\text { Biyearly } \\
\text { probability }\end{array}$} & \multirow{2}{*}{$\begin{array}{c}\begin{array}{c}\text { Annual } \\
\text { probability }\end{array} \\
{ }_{12} q_{24} \\
(24-35)\end{array}$} \\
\hline & & $\begin{array}{l}q_{0} \\
(0)\end{array}$ & $\begin{array}{l}q_{1} \\
(1)\end{array}$ & $\begin{array}{l}q_{2} \\
(2)\end{array}$ & $\begin{array}{c}{ }_{3} q_{3} \\
(3-5)\end{array}$ & $\begin{array}{l}{ }_{3} q_{6} \\
(6-8)\end{array}$ & $\begin{array}{c}{ }_{3} q_{9} \\
(9-11)\end{array}$ & $\begin{array}{c}{ }_{6} q_{12} \\
(12-17)\end{array}$ & $\begin{array}{c}{ }_{6} q_{18} \\
(18-23)\end{array}$ & \\
\hline 1 & Oesterreich unter der Enns & 122.8 & 117.6 & 115.4 & 116.7 & 113.1 & 113.6 & - & - & - \\
\hline 2 & Oesterreich ob der Enns & 129.8 & 132.1 & 121.7 & 127.4 & 122.3 & 105.2 & 101.6 & 110.6 & 113.6 \\
\hline 3 & Salzburg & 125.3 & 135.2 & 111.2 & 138.0 & 118.4 & 96.1 & 84.8 & 63.3 & 105.1 \\
\hline 4 & Steiermark & 133.8 & 130.1 & 129.1 & 132.2 & 119.4 & 120.5 & 111.6 & 113.1 & 117.2 \\
\hline 5 & Kärnthen & 135.5 & 115.8 & 132.1 & 133.3 & 121.8 & 104.7 & 106.3 & 85.3 & 99.6 \\
\hline 6 & Krain & 133.4 & 146.4 & 137.3 & 130.2 & 118.3 & 114.2 & 110.6 & 115.2 & 112.0 \\
\hline 7 & $\begin{array}{l}\text { Görz, Gradisca und Istrien, } \\
\text { Triest sammt Gebiet }\end{array}$ & 122.7 & 112.2 & 126.0 & 125.1 & 110.4 & 116.1 & 106.4 & 98.7 & 90.4 \\
\hline 8 & Tirol und Vorarlberg & 125.9 & 136.0 & 140.9 & 118.0 & 114.8 & 92.1 & 96.6 & 104.2 & 98.4 \\
\hline 9 & Böhmen & 126.0 & 120.0 & 120.1 & 124.2 & 119.1 & 107.2 & 107.0 & 108.4 & 104.9 \\
\hline 10 & Mähren & 135.6 & 115.9 & 122.9 & 134.9 & 118.3 & 118.5 & 112.4 & 109.3 & 107.9 \\
\hline 11 & Schlesien & 117.9 & 105.8 & 103.0 & 122.2 & 113.6 & 110.0 & 118.6 & 105.0 & 101.6 \\
\hline 12 & Krakau sammt Gebiet & 129.9 & 144.0 & 117.8 & 136.1 & 145.7 & 105.5 & 111.5 & 118.3 & 99.4 \\
\hline 13 & Galizien & 126.2 & 120.5 & 112.0 & 122.9 & 113.8 & 102.2 & 103.5 & 102.4 & 102.6 \\
\hline 14 & Bukovina & 116.5 & 115.4 & 102.8 & 103.5 & 94.2 & 100.1 & 99.1 & 94.1 & 80.4 \\
\hline 16 & Lombardie & 129.9 & 117.8 & 123.9 & 121.6 & 118.3 & 111.9 & 106.1 & 105.9 & 100.9 \\
\hline 17 & Venedig & 111.5 & 108.5 & 110.2 & 96.0 & 114.8 & 106.8 & 102.5 & 99.7 & 99.2 \\
\hline 18 & Ungern & 116.9 & 113.6 & 118.9 & 118.7 & 113.1 & 102.6 & 101.7 & 100.0 & 105.8 \\
\hline 19 & $\begin{array}{l}\text { Serbische Wojwodschaft und } \\
\text { Temeser Banat }\end{array}$ & 121.4 & 110.1 & 111.2 & 122.8 & 107.9 & 101.4 & 102.5 & 103.6 & 98.2 \\
\hline 21 & Siebenbürgen & 126.0 & 113.4 & 111.2 & 103.5 & 111.8 & 105.3 & 103.0 & 97.6 & 109.1 \\
\hline 22 & Militärgränze & 115.1 & 111.2 & 114.5 & 110.3 & 108.6 & 104.6 & 98.9 & 99.3 & 99.7 \\
\hline & Total Empire $\left(^{*}\right)$ & 122.1 & 116.9 & 118.0 & 120.5 & 114.8 & 105.4 & 104.2 & 102.6 & 103.9 \\
\hline
\end{tabular}

$\left.{ }^{*}\right)$ Oesterreich unter der Enns, Dalmatien, and Kroatien und Slavonien not included.

We further investigate these aspects through use of Bourgeois-Pichat's (1951) decomposition method between exogenous and endogenous infant mortality components, extending this method to the analysis of deaths up until the third birthday separately for males and females. If the sex ratio for endogenous mortality had been more favourable to female infants relative to the ratio observed for exogenous mortality, then there may have been an under-registration of neonatal female mortality. 
Generally, for all of the Empire, mortality up until three years of age (344\%) is decomposed between endogenous mortality (87\%, equal to $25 \%$ ) and exogenous mortality (257\%o, equal to $75 \%$ ). The ratio between female and male exogenous mortality is much less variable than the analogous endogenous ratio, and in only a few cases does exogenous female mortality resemble that of male mortality. These cases include Salzburg, Tirol und Vorarlberg, Serbische, and Militärgränze; while Venedig, and above all Bukovina, are the only Länder in which exogenous female mortality surpasses male mortality. With regard to the lowest ratio levels, only Steiermark and Krain have values that fall below 0.9, but these two regions are also among the Länder with the lowest mortality rates between the ages of 0-2. Figure 14 and Table 17 show that the Länder "suspected" of under-registering endogenous female mortality are Krain, Krakau, Bukovina, and Galizien, which coincide quite closely with - when observing the probabilities of death in the first three years of life independently of sex the areas in which we noted that neonatal mortality seemed too low with respect to the months which followed (see above).

Figure 14: Ratios of male to female endogenous and exogenous mortality rates, ages 0-2 years. Cohort born in 1851 in the Länder of the Austrian Empire (*)

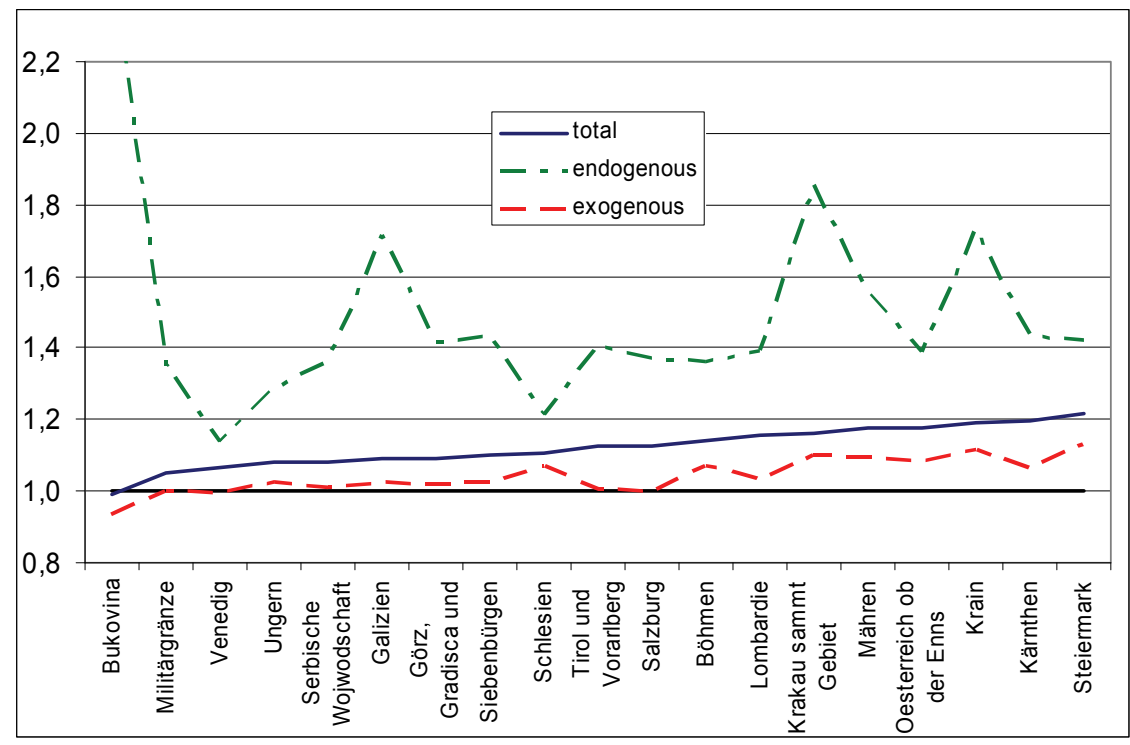

(*) Länder are ordered by ratio of male to female under-3 mortality, from lower to highest. 
Table 17: Ratio male to female mortality, ages 0-2 years: total, endogenous and exogenous mortality. Cohort born in 1851 in the Länder of the Austrian Empire

\begin{tabular}{|c|c|c|c|c|}
\hline \multirow[b]{2}{*}{$\mathbf{n}$} & \multirow[b]{2}{*}{ Länder } & \multicolumn{3}{|c|}{ ratio male to female mortality } \\
\hline & & ${ }_{3} q_{0}$ (total) & ${ }_{3} q_{0}$ (endo) & ${ }_{3} q_{0}(e \times 0)$ \\
\hline 2 & Oesterreich ob der Enns & 1.177 & 1.388 & 1.084 \\
\hline 3 & Salzburg & 1.128 & 1.372 & 1.002 \\
\hline 4 & Steiermark & 1.216 & 1.423 & 1.130 \\
\hline 5 & Kärnthen & 1.196 & 1.430 & 1.064 \\
\hline 6 & Krain & 1.191 & 1.735 & 1.118 \\
\hline 7 & Görz, Gradisca und Istrien, Triest sammt Gebiet & 1.093 & 1.416 & 1.023 \\
\hline 8 & Tirol und Vorarlberg & 1.128 & 1.409 & 1.005 \\
\hline 9 & Böhmen & 1.142 & 1.364 & 1.071 \\
\hline 10 & Mähren & 1.176 & 1.555 & 1.098 \\
\hline 11 & Schlesien & 1.104 & 1.211 & 1.072 \\
\hline 12 & Krakau sammt Gebiet & 1.161 & 1.855 & 1.099 \\
\hline 13 & Galizien & 1.092 & 1.713 & 1.027 \\
\hline 14 & Bukovina & 0.990 & 2.498 & 0.937 \\
\hline 16 & Lombardie & 1.157 & 1.392 & 1.038 \\
\hline 17 & Venedig & 1.067 & 1.134 & 0.995 \\
\hline 18 & Ungern & 1.080 & 1.286 & 1.025 \\
\hline 19 & Serbische Wojwodschaft und Temeser Banat & 1.083 & 1.362 & 1.011 \\
\hline 21 & Siebenbürgen & 1.100 & 1.430 & 1.025 \\
\hline \multirow[t]{2}{*}{22} & Militärgränze & 1.049 & 1.352 & 1.001 \\
\hline & Total Empire $\left({ }^{*}\right)$ & 1.106 & 1.347 & 1.036 \\
\hline
\end{tabular}

$\left({ }^{*}\right)$ Oesterreich unter der Enns, Dalmatien, and Kroatien und Slavonien not included.

Further study of these gender differences can be pursued through use of a technique proposed by Hill and Upchurch (1995). These authors built a kind of standard difference between female and male infant mortality, which varies with mortality rates. They observed the relationship between male mortality up to five years of age, and the ratio between female and male mortality at ages $0,1-4$, and 0-4. Interpolating the three clouds of points with a curve and smoothing, Hill and Upchurch obtained the ratio between the probabilities of female and male death expected for the three ages, given a certain level of male mortality at ages $0-4$. To carry out their estimates, they used data extracted from the 1820-1964 life tables of several Central European countries and New 
Zealand (all tables considered to be of high quality). They compared their expected results with those actually found in recent investigations conducted in different developing countries, building a measure of discrimination disfavouring female children; or, to be more exact, as clarified by the authors, the actual discrimination in several developing countries with respect to the discrimination in countries more than a century ago, which were chosen to build the tables (Hill and Upchurch 1995:132)

Our data allow us to build probabilities of death only up until the third birthday, and thus a direct comparison with Hill and Upchurch's standard tables is not possible. On the other hand, it is feasible to construct the same relationships observed by the two authors using data on male mortality at ages 0-2 in the 19 Länder for which data are available (Table 18 and Figure 15). The index of discrimination is calculated as the difference between the actual ratio $\mathrm{q}_{\mathrm{F}} / \mathrm{q}_{\mathrm{M}}$, and the theoretical ratio if gender discrimination were the mid-19 ${ }^{\text {th }}$-century Austrian Empire's "average," as expressed by the interpolating line.

Figure 15: Ratios of female to male mortality rates in childhood by mortality level. Cohort born in 1851 in the Länder of the Austrian Empire

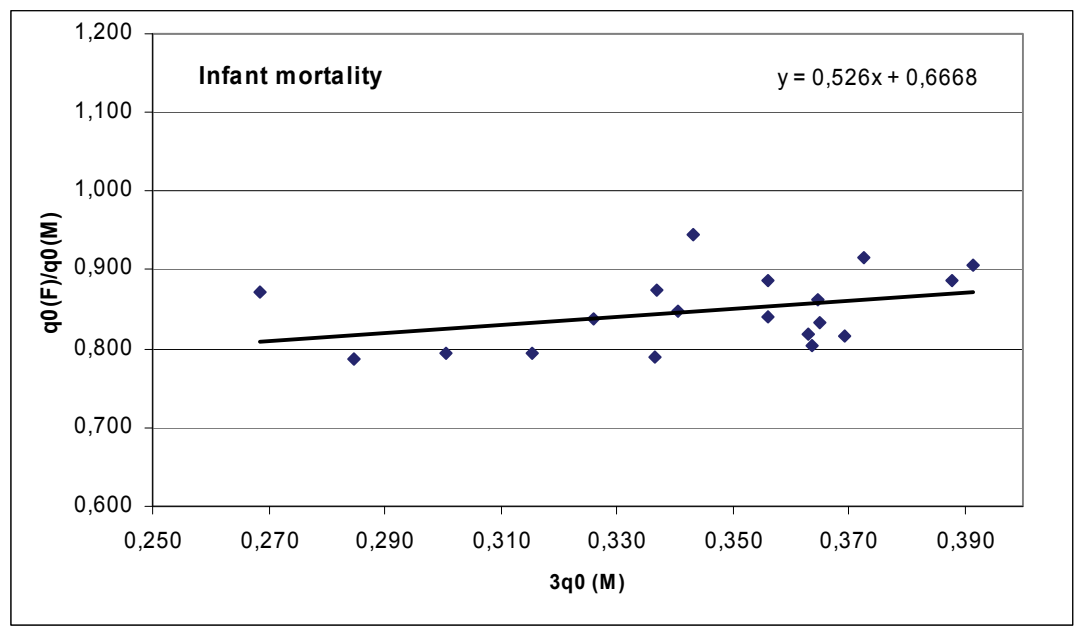


Figure 15: (Continued)
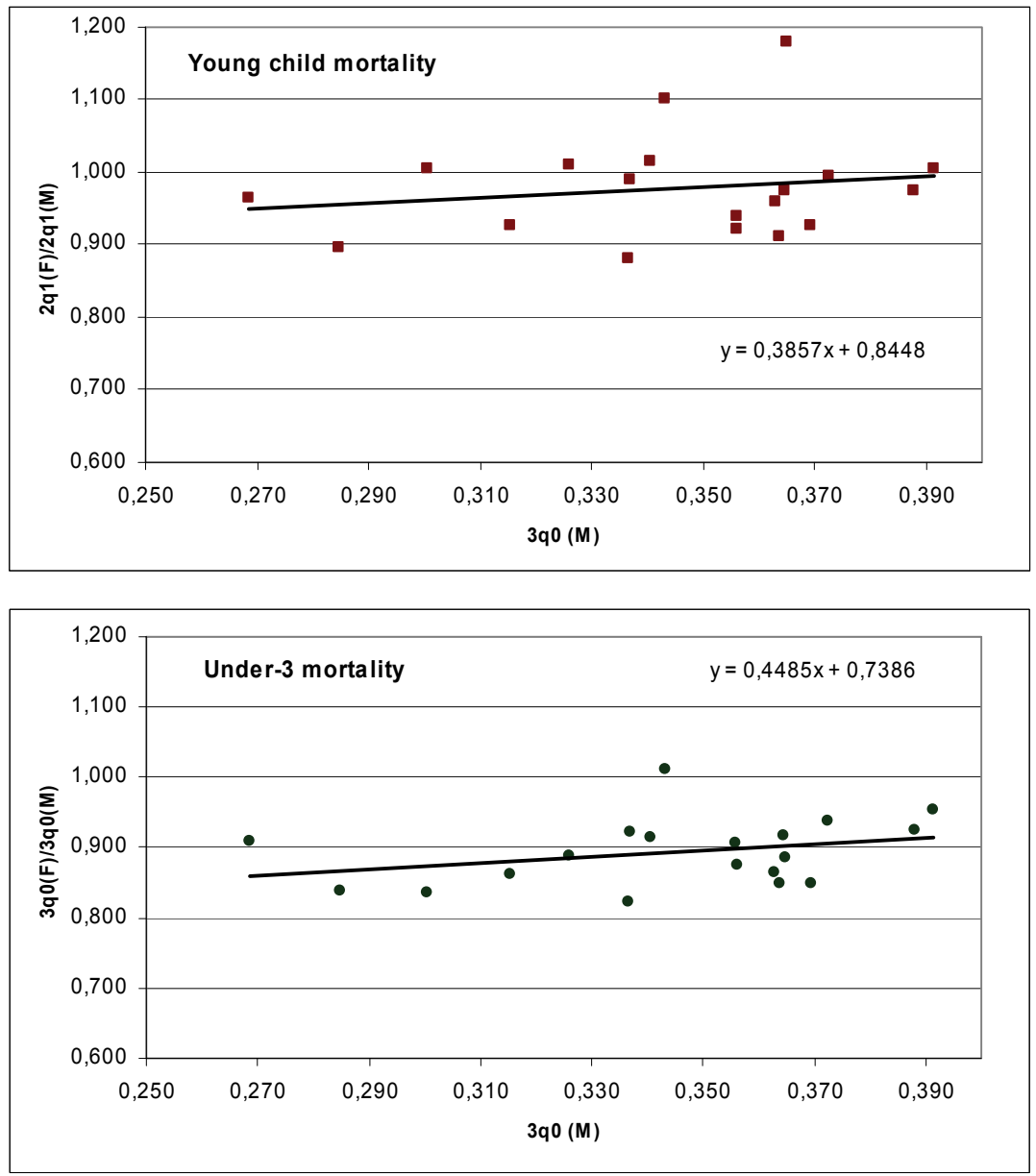
Table 18: Index of female mortality disadvantage (*). Cohort born in 1851 in the Länder of the Austrian Empire

\begin{tabular}{|c|c|c|c|c|}
\hline \multirow[b]{2}{*}{$\mathbf{n}$} & \multirow[b]{2}{*}{ Länder } & \multicolumn{3}{|c|}{$\begin{array}{c}\text { Index of female mortality } \\
\text { disadvantage }\end{array}$} \\
\hline & & $\begin{array}{c}\text { infant } \\
q_{0}\end{array}$ & $\begin{array}{l}\text { young } \\
{ }_{2} q_{1}\end{array}$ & $\begin{array}{c}\text { under } 3 \\
{ }_{3} q_{0}\end{array}$ \\
\hline 2 & Oesterreich ob der Enns & -0.045 & -0.062 & -0.055 \\
\hline 3 & Salzburg & -0.027 & 0.194 & -0.016 \\
\hline 4 & Steiermark & -0.053 & -0.093 & -0.067 \\
\hline 5 & Kärnthen & -0.031 & 0.044 & -0.037 \\
\hline 6 & Krain & -0.030 & -0.059 & -0.027 \\
\hline 7 & Görz, Gradisca und Istrien. Triest sammt Gebiet & 0.002 & 0.039 & 0.023 \\
\hline 8 & Tirol und Vorarlberg & -0.001 & 0.040 & 0.002 \\
\hline 9 & Böhmen & -0.014 & -0.042 & -0.023 \\
\hline 10 & Mähren & -0.054 & -0.073 & -0.052 \\
\hline 11 & Schlesien & 0.031 & -0.062 & 0.007 \\
\hline 12 & Krakau sammt Gebiet & -0.038 & -0.039 & -0.019 \\
\hline 13 & Galizien & 0.005 & -0.011 & 0.014 \\
\hline 14 & Bukovina & 0.098 & 0.123 & 0.118 \\
\hline 16 & Lombardie & -0.040 & -0.025 & -0.037 \\
\hline 17 & Venedig & 0.052 & 0.006 & 0.032 \\
\hline 18 & Ungern & 0.015 & -0.021 & 0.013 \\
\hline 19 & Serbische Wojwodschaft und Temeser Banat & 0.031 & 0.015 & 0.033 \\
\hline 21 & Siebenbürgen & 0.064 & 0.016 & 0.050 \\
\hline 22 & Militärgränze & 0.034 & 0.010 & 0.039 \\
\hline
\end{tabular}

*) The actual ratio of female to male mortality minus the expected ratio according to the average situation of the Empire.

A comparison of our results with those obtained by Hill and Upchurch for developing countries where significant discrimination against female children exists today allows us to surmise that, among the Austrian Empire Länder, female infants were not particularly penalised (Table 18). The differences with a positive sign indicating higher female mortality than expected - are relatively low, with the exception of Bukovina (which for all ages has higher differences), Siebenbürgen (which has somewhat notable differences in the first year of life), and Salzburg (which has a large difference only for the age classes 1-2; although the results could be skewed by small numbers). Large differences with a negative sign could instead indicate less female mortality. These cases are, however, rare, and are limited to Steiermark, Mähren, and perhaps Oesterreich ob der Enns. 
The results illustrated thus far could be disproved in part if an under-registering of precocious female deaths could be shown to have taken place (due, for example, to exposure or to abandonment in inappropriate places) precisely in the areas where female infants were most neglected. Our impression is, however, that this problem - if present - was relatively contained. In the first place, even when taking into account the "suspected" exceptions mentioned above, the dispersion of the points around the interpolating line is not greater than that observed for countries whose statistics have been judged to be very reliable (cfr. Figure 15 and Hill and Upchurch's Figure 1 (Hill and Upchurch 1995:131)). In the second place, the sign of the index for the first year of life is almost always the same as that observed in the following two-year period. On the contrary, in the case of significant under-registration of neonatal female deaths, we should have found sign reversals precisely in the regions - like Bukovina - where female infants were most neglected. Finally, the indicators in Table 18 delineate - with few exceptions - two areas: the centre-north (with a negative sign) and the south-east (with a positive sign). This territorial regularity could indicate different levels of gender discrimination.

We conclude this section with a brief comment on mortality differences by legitimacy. During the first period of life, mainly the first year, mortality is higher for illegitimate births in all of the Länder. Table 19 and Figure 16 show that the difference in survival between illegitimate and legitimate infants is not lower where illegitimacy is higher. The story is likely more complicated, and related to local peculiarities and nuptiality patterns, as shown for Austria by Priox (1993). 
Table 19: Life tables for the first 36 months of life. Cohort born in 1851 in the Länder of the Austrian Empire. Death probability $1000 \mathrm{x}_{\mathrm{n}} \mathrm{q}_{\mathrm{x}}$ for legitimate and illegitimate births. Länder grouped by level of illegitimacy (*)

\begin{tabular}{|c|c|c|c|c|c|c|c|c|c|}
\hline \multirow[b]{3}{*}{$\begin{array}{l}\text { Legitimacy } \\
\text { Länder group }\end{array}$} & \multicolumn{9}{|c|}{ Age (months) } \\
\hline & \multicolumn{3}{|c|}{ Monthly probability } & \multicolumn{3}{|c|}{ Quarterly probability } & \multicolumn{2}{|c|}{$\begin{array}{c}\text { Biyearly } \\
\text { probability }\end{array}$} & \multirow{2}{*}{$\begin{array}{c}\begin{array}{c}\text { Annual } \\
\text { probability }\end{array} \\
{ }_{12} q_{24} \\
(24-35)\end{array}$} \\
\hline & $\begin{array}{l}q_{0} \\
(0)\end{array}$ & $\begin{array}{l}q_{1} \\
(1)\end{array}$ & $\begin{array}{l}q_{2} \\
(2)\end{array}$ & $\begin{array}{c}{ }_{3} q_{3} \\
(3-5)\end{array}$ & $\begin{array}{c}{ }_{3} q_{6} \\
(6-8)\end{array}$ & $\begin{array}{c}{ }_{3} q_{9} \\
(9-11)\end{array}$ & $\begin{array}{c}{ }_{6} q_{12} \\
(12-17)\end{array}$ & $\begin{array}{c}{ }_{6} q_{18} \\
(18-23)\end{array}$ & \\
\hline \multicolumn{10}{|c|}{ Legitimate births } \\
\hline High & 109.9 & 25.2 & 23.3 & 41.7 & 27.3 & 23.2 & 34.7 & 18.3 & 32.4 \\
\hline Medium & 93.7 & 25.0 & 20.4 & 38.7 & 31.6 & 37.2 & 47.0 & 38.1 & 52.5 \\
\hline Low & 131.7 & 24.2 & 17.9 & 32.9 & 24.8 & 35.0 & 46.3 & 43.7 & 58.2 \\
\hline Total & 116.1 & 24.5 & 19.1 & 35.6 & 27.6 & 35.4 & 46.1 & 40.5 & 54.9 \\
\hline \multicolumn{10}{|c|}{ Illegitimate births } \\
\hline High & 149.9 & 53.4 & 43.1 & 67.7 & 39.0 & 30.5 & 40.6 & 19.2 & 29.5 \\
\hline Medium & 140.7 & 47.0 & 38.4 & 63.4 & 42.2 & 44.5 & 58.3 & 42.1 & 51.0 \\
\hline Low & 158.5 & 48.1 & 36.7 & 54.3 & 30.9 & 35.7 & 43.0 & 39.3 & 43.4 \\
\hline \multirow[t]{2}{*}{ Total } & 146.7 & 48.2 & 38.7 & 61.7 & 38.8 & 40.1 & 51.6 & 37.9 & 45.6 \\
\hline & \multicolumn{9}{|c|}{100 x Ratio Illegitimates/Legitimates } \\
\hline High & 136.3 & 211.7 & 184.7 & 162.2 & 142.9 & 131.7 & 117.1 & 104.9 & 91.1 \\
\hline Medium & 150.1 & 187.7 & 188.0 & 163.9 & 133.6 & 119.8 & 124.1 & 110.6 & 97.0 \\
\hline Low & 120.4 & 199.1 & 205.2 & 164.9 & 124.5 & 102.1 & 92.9 & 89.9 & 74.5 \\
\hline Total & 126.4 & 196.5 & 202.4 & 173.5 & 140.5 & 113.3 & 111.9 & 93.6 & 83.0 \\
\hline
\end{tabular}

$\left({ }^{*}\right)$ High level of illegitimacy (20\% or higher during 1851-54): Oesterreich ob der Enns, Salzburg, Steiermark, and Karnthen. Medium (5-20\%): Krain, Görz Gradisca und Istrien Triest sammt Gebiet, Tirol und Vorarlberg. Böhmen, Mähren, Schlesien, Krakau sammt Gebiet, Galizien, and Bukovina. Low (5\% or lower): Lombardie, Venedig, Ungern, Serbische Woiwodschaft und Temeser Banat, Siebenburgen, and Militargranze. 
Figure 16: Life tables for the first 36 months of life. Cohort born in 1851 in the Länder of the Austrian Empire. Survival function $I_{x}$ for legitimate and illegitimate births by level of illegitimacy (*)

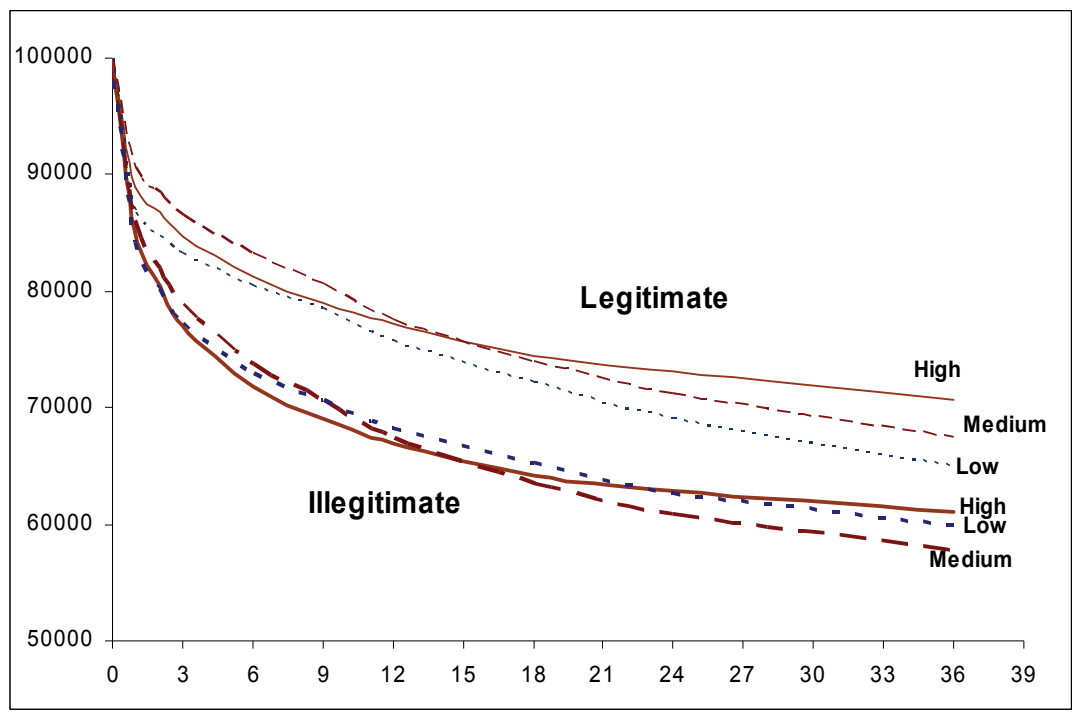

(*) High level of illegitimacy (20\% or higher during 1851-54): Oesterreich ob der Enns, Salzburg, Steiermark, and Kärnthen. Medium (5-20\%): Krain, Görz Gradisca und Istrien Triest sammt Gebiet, Tirol und Vorarlberg, Böhmen, Mähren, Schlesien, Krakau sammt Gebiet, Galizien, and Bukovina.

Low (5\% or lower): Lombardie, Venedig, Ungern, Serbische Woiwodschaft und Temeser Banat, Siebenbürgen, and Militärgränze.

\section{Conclusions}

The Tafeln zur Statistik der Österreichischen Monarchie are a valuable source of data. These mid- $19^{\text {th }}$-century tables represent an immense achievement on the part of a powerful political machine (which, by the 1850s, had been running strong for 20 years), involving all of the administrative apparatus governing the Austrian Empire's 35 million inhabitants. Among the types of information gathered, that on infant births and deaths is of considerable importance, not least for the particular attention paid to detail, which was rarely found even in the decades that followed. This article demonstrates that - with several exceptions and some basic cautions - the material on infant mortality 
published in the Tafeln around 1850 guarantees reliable comparability between the Empire's Länder. The greatest obstacles are the likely under-registration of neonatal deaths - especially of females - in several north-eastern Länder, particularly Bukovina and Galizien, and the rather unusual age-heaping, mainly with regard to ages ending in 9. In addition, data on stillbirths are difficult to use because the criteria employed to collect such information not only differed from those used today, but they also varied from area to area. Apart from these issues, the data are of good quality, in that sex, age at death, and legitimacy were all recorded with accuracy.

This article, which is of a methodological nature, provides only a few examples of potential analyses which might be carried out using such rich and detailed territorial data. The geography of mortality in the first three years of life varied by age, but according to intervals that differ from those usually employed when studying early mortality. Four ages can be identified (first month, months 1-5, months 6-17, and months 18-35) with a geography of differing mortality. In all likelihood, in each of these age groups, the reasons for the mortality differences between Länder were diverse. Life tables differentiated by sex and more sophisticated life models (those proposed by Bourgeois-Pichat in 1951 and by Hill and Upchurch in 1995) suggest that, in the south-eastern area of the Empire, female children were more heavily penalized than in the north-western regions, albeit to a much lesser extent than that observed in several of today's poorer countries. Finally, the diffusion of births outside of wedlock varied significantly: levels were quite high in the heart of today's Austria; medium levels were seen in the other Austrian regions, in the transalpine areas bordering Austria, and in the regions west of the Empire; and very low levels were found in the southern Länder. The direct relationship between mortality and illegitimacy were found to persist everywhere, regardless of the level of illegitimacy.

Validation of the quality of infant mortality data contained in the Tafeln around the mid- $19^{\text {th }}$ century opens up interesting directions for future research. First, it will be possible to construct long series of infant mortality indicators using the complete Tafeln data from 1829 to 1871 , and to connect these series to data available for the following periods. In addition, the previous years may be taken into account, as Volume II of the Tafeln of 1829, Table 6.1 contains births and deaths (including infant deaths) for 18191828: year-by-year for the Empire without Hungary, and totals for the 10-year period for its provinces. Second, in-depth investigations of the underlying reasons for territorial differences could be pursued by linking infant mortality indicators with other quantitative variables (education, religion, social stratification, etc. - many of which are obtainable from the Tafeln themselves). Third, the good quality of the aggregated data should encourage the collection of elementary or intermediate data (by districts or provinces) which - once aggregated - form the basis of the data on infant births and deaths published in the Tafeln. This project is currently underway for the region of 
Venedig, and thus far has provided encouraging results (Clerici 1991; Dalla-Zuanna and Rosina 2008). Finally, indicators on infant mortality could be used to reconstruct the different demographic regimes that existed among the Austrian Empire Länder during the $19^{\text {th }}$ century, and to observe the first signs of the Demographic Transition. 


\section{References}

Bengtsson, T., Campbell, C., and Lee, J.Z. (2004). Life under pressure: Mortality and living standards in Europe and Asia, 1700-1900. Cambridge, Mass.: MIT Press.

Bideau, A., Desjardins, B., and Pérez Brignoli, H. (1997). Infant and child mortality in the past. Oxford, UK: Clarendon Press.

Bourgeois-Pichat, J. (1951). La mesure de la mortalité infantile. I. Principes et méthods. Population 6(2): 233-248. http://www.jstor.org/stable/1524151.

Breschi, M. and Pozzi, L. (2004). The determinants of infant and child mortality in past European populations. Udine: Forum Edizioni.

Clerici, R. (1991). La transizione demografica nelle province venete. In: Rossi, F. (ed.). La transizione demografica nel Veneto. Venezia: Fondazione Corazzin Editrice: 41-72.

Corsini, C.A. and Viazzo, P.P. (1997). The decline of infant and child mortality. The European experience: 1750-1990. The Hague: Martinus Nijhoff Publishers.

Dalla-Zuanna, G. and Rosina, A. (2008). The fatal season. A study of extremely high 18th and 19th century winter neonatal mortality in north-eastern Italy. Padova: University of Padova, Department of Statistical Sciences (Working Papers n. 14)

Ediev, D.M. (2003) Demographic losses of deported Soviet people. Agrus: Stavropol.

Ediev, D.M. and Gisser, R. (2007). Reconstruction of historical series of life tables and of age-sex structures for the Austrian population in the 19th and the first half of the 20th century. Vienna Yearbook of Population Research 2007: 327-355. doi:10.1553/populationyearbook2007s327.

Findl, P. (1979). Mortalität und Lebenserwartung in den österreichischen Alpenländern im Zeitalter der Hochindustrialisierung (1868-1912). In: Geschichte und Ergebnisse der zentralen amtlichen Statistik in Österreich 1829-1979. Wien: Österreichisches Statistisches Zentralamt: 425-452.

Grandi C. (1995). All'altare col permesso: amore e burocrazia nel Trentino asburgico. In: Pasi, A. and Sorcinelli, P. (eds.). Amori e trasgressioni. Rapporti di coppia tra '800 e '900. Bari: edizioni Dedalo: 189-225.

Hill, K. and Upchurch, D.M. (1995). Gender Differences in Child Health: Evidence from the Demographic and Health Surveys. Population and Development Review 21(1): 127-151. doi:10.2307/2137416. 
Istat (1976). Sommario di statistiche storiche dell'Italia 1861-1975. Roma: ISTAT.

Kytir, J., Köck, C., and Münz, R. (1995). Historical regional patterns of infant mortality in Austria. European Journal of Population 11(3): 243-259. doi:10.1007/BF01264949.

Lee, C.H. (1991). Regional inequalities in infant mortality in Britain, 1861-1971: Patterns and hypotheses. Population Studies 45(1): 55-65. doi:10.1080/0032472031000145086.

Livi Bacci, M. (1997). Introduction. In: Bideau, A., Desjardins, B., and Pérez Brignoli, H. (eds.). Infant and child mortality in the past. Oxford, UK: Clarendon Press: 1-4.

Livi Bacci, M. (1999) Introduzione alla demografia. Torino: Loescher editore. (3rd ed.).

Meners Konversation-Lexicon. (1896). Vol. 15, Leipzig und Wien. Bibliographisches Institut.

Preston, S.H. and Haines, M.R. (1991). Fatal Years: Child mortality in late nineteenthcentury America. Princeton, NJ, USA: Princeton University Press.

Prioux, F. (1993). Aspects régionaux de la formation de la famille et de l'illégitimité en Autriche. Population (French Edition) 48(3): 711-734. http://www.jstor.org/ stable/1534102.

Rossi, F. and Tesolat, F. (2006). Analisi della stagionalità in un contesto di alta mortalità infantile. Adria, 1675-1900. Popolazione e Storia 2006(1): 31-55.

Vallin, J. (1991). Mortality in Europe from 1720 to 1914: Long-term trends and changes in patterns by age and sex. In: Schofield, R., Reher, D., and Bideau, A. (eds.). The decline of mortality in Europe. Oxford, UK: Clarendon Press: 38-67.

Viazzo, P.P. (1997). Alpine patterns of infant mortality in perspective. In: Bideau, A., Desjardins, B., and Pérez Brignoli, H. (eds.). Infant and child mortality in the past. Oxford, UK: Clarendon Press: 61-73.

Wrigley, E.A., Davies, R.S., Oeppen, J.E., and Schofield, R.S. (1997). English population history from family reconstitution 1580-1837. Cambridge: Cambridge University Press. 
Dalla-Zuanna \& Rossi: Comparisons of infant mortality, Austrian Empire 1851-54 